\title{
KEEFISIENAN MODEL BLENDED LEARNING TERHADAP MOTIVASI DAN \\ TINGKAT PEMAHAMAN SERTA PENGEMBANGAN MODUL UNTUK \\ MAHASISWA PADA MATA KULIAH ALGORITMA DAN PEMROGRAMAN
}

\author{
Sa’i Frida Rejeki (0305202056) \\ Program Studi Pendidikan Matematika-2 \\ Fakultas Ilmu Tarbiah dan Keguruan UIN Sumatera Utara \\ Jl. Wiliam Iskandar Pasar V, Medan Estate \\ Email : saifrida651@gmail.com
}

\begin{abstract}
Abstrak
Algoritma adalah suatu metode atau langkah-langkah yang efektif yang telah disusun secara tertulis dan secara berurutan yang berisikan kumpulan perintah untuk menyelesaikan suatu permasalahan yang dimana setelah itu perlu diselesaikan secara sistematis. Analisis tinjauan pada studi pendidikan matematika terhadap artikel atau tulisan yang membahas mengenai Kemampuan Mahasiswa Mata Kuliah Algoritma Pemprogaman ini bertujuan agar mahasiswa memahami lebih dalam tentang algoritma dan pemrogaman. Mata kuliah algoritma dan pemrograman khusus diarahkan untuk mahasiswa agar mahasiswa dapat mengembangkan pengetahuan kognitif dan motorik para mahasiswa terhadap asepek-aspek tertentu. Selain itu, tujuan dari penelitian ini yaitu sebagai bahan ajar modul algoritma dan pemprogaman yang berbasis problem based learning, sebagai pemahaman pembelajaran blended learning dan pembelarajaran konvesional. Jenis penelitian dari model blended learning adalah quasi eksperimental Langkah yang digunakan dari pengembangan modul adalah pendefinisian, perencanaan, pengembangan, dan diseminasi. Dengan studi literatur ini mahasiswa dapat memahami dapat memahami dan lebih mengerti tentang maksud dan tujuan dari mata kuliah algoritma dan pemprograman, seperti contohnya mahasiswa dapat memahami tentang hal konsep serta konstruksi dasar dalam algoritma ke dalam bahasa pemprograman.
\end{abstract}

Kata kunci: Algoritma Pemrograman, Blanded Learning, Modul 


\section{PENDAHULUAN}

Pengembangan dalam bidang pendidikan sudah diatur dalam Undang-Undang Nomor 20 Tahun 2003 Pasal 3 tentang Sistem Pendidikan Naional bahwasannya pendidikan nasional berfungsi dalam mengembangkan kemampuan seseorang dalam rangka mencerdaskan kehidupan bangsa yg memiliki tujuan untuk mengembangkan potensi peserta didik agar menjadi insan yang berguna.

Kemajuan teknologi dan informasi dengan seiring berkembang pesatnya kemajuan teknologi yang mengakibatkan terjadinya perkembangan yang sangat pesat di berbagai bidang ilmu. Dengan adanya kemajuan dari ilmu pengetahuan di berbagai bidang kehidupan tidak lepas dari dalam bidang pendidikan yang membawa perubahan peningkatan terhadap pendidikan. Seperti aplikasi matematika sebagai pendukung bidang ilmu lain juga mengalami perkembangan,misalnya pemprogaman. Di masa yang akan datang perkembangan pendidikan tidak akan lepas dari beberapa faktor yang mempengaruhinya. Dalam situasi inilah dalam bidang pendidikan dan pembelajaran diperlukan adanya suatu pembaruan yang secara terus menerus tanpa adanya perhentian agar pendidikan setiap tahunnya selalu maju. Dengan adanya perubahan yang bertujuan untuk meningkatkan kualitas pendidikan dan pembelajaran sudah termasuk ke dalam contoh dari hasil pendidikan dan pembelajaran.

Deskrpisi dari makna memahami sistem pendidikan nasional ialah landasan penyelenggaran pendidikan dijadikan sebagai pesan moral dan tercapainya cita-cita perjuangan bangsa Indonesia sebagai sarana. Sedangkan deskripsi dari tujuan penelitian ialah menyuplai tenaga kerja dengan kebutuhan lapangan kerja seperti memiliki pengetahuan yang luas serta memiliki keterampilan yang unik serta menyuplai tenaga kerja yang dapat menerima dan beradaptasi dalam perkembangan teknologi. Dalam prosesnya juga perlu menumbuhkan pada seluruh mahasiswa tentang pentingya keterampilan dan kemajuan informasi, sikap independen, dan rasa harapan untuk keberhasilan dalam karir sepanjang hayat.

Pembelajaran yang tersusun terdapat beberapa elemen yang satu saling mendukung. Seperti yang telah dikemukakan oleh Pribadi (2019) bahwasannya pengkajian dapat dipandang sebagai suatu sistem dengan elemen-elemen yang saling terkait agar tercapainya penguasaan wawasan, kemahiran, dan tindakan oleh peserta didik yang diperlukan untuk melakukan suatu kegiatan. 
Mahasiswa merasakan ada kekurangan pada saat belajar yang diperoleh dari internet,seperti yaitu kurangnya tersedia entitas tertentu pada bab serta adanya variasi pernyataan dari berbagai sumber. Sedangkan, materi ajar lain dari dosen atau buku konvesional, yaitu buku berupa modul yang telah dikembangkan oleh dosen sebagai fasilitas mata kuliah algoritma pemprogaman belum ada.

Kemampuan mahasiswa dalam memecahkan suatu permasalahan sangat rendah. Salah satu penyebabnya yaitu kurangnya mendalami entitas yang disampaikan oleh dosen. Hanya beberapa mahasiswa saja yang rajin dalam hal mencari sumber pembelajaran yang lain. Selain itu mahasiswa hanya akan menyalin apa yang disampaikan oleh dosen tanpa memhami alur dan fungsi dari kode-kode didalamnya. Contohnya adalah program dan penyelesaiannya, serta latihan soal untuk dipraktikkan ke mahasiswa.

Masalah yang terjadi pada mahasiwa tersebut dapat diberikan resolusi, salah satunya adalah dengan mengimplementasikan versi pengkajian problem based learning. Menurut Sudarman (2014) suatu pendekatan pengkajian yang menggunakan masalah dunia nyata sebagai konteks bagi peserta didik agar memiliki pola pikir yang kritis dan memliki keterampilan dalam memecahkan suatu hal masalah merupakan deskripsi dari versi pengkajian based learning. Menurut Sanjaya (2009) Karakteristik dalam model pengkajian based learning adalah kegiatan pengkajian yang dilakukan mahasiswa tidak hanya mendengarkan penjelasan dari dosen, menjiplak, dan mengingat materi tetapi mahasiswa harus andal dalam berkomunikasi, berpendapat,dan mengolah data sesuai dengan permasalahan yang diajukan oleh dosen. Hal ini sejalan dengan kompendium di perguruan tinggi yaitu lebih berpusat ke mahasiswa dan dosen hanya sebagai penyedia.

\section{PEMBAHASAN}

Dalam partikulasi mata kuliah khususnya dalam metode pendidikan seperti sistem pada belajar mengajar metode pembelajaran yang dilakukan dosen yaitu dengan memantau penggunaan dari model pembelajaran apakah sesuai dengan mata kuliah yang diajarkan.Mutu dan hasil belajar dipengaruhi oleh pemilihan model pembelajaran yang akan digunakan. Menuntut adanya peningkatan, pembaruan, dan peralihan sepanjang masa merupakan suatu sistem mempelajaran. 
Dosen menyediakan informasi, bahan bacaan, dan materi kuliah untuk mahasiswa dengan menggunakan teknologi komputer untuk mengakses internet. Beberapa dosen memungkinkan mahasiswa untuk berinteraksi satu sama lain dengan menggunakan teknologi komunikasi asynchronous dan synchronous. Komunikasi asynchronous dideskripsikan sebagai tugas yang berlangsung di waktu dan posisi yang berbeda (Fenton \& Watkins, 2010). Komunikasi synchronous dideskripsikan bagaikan tugas yang terjadi secara nyata, dimana mahasiswa dan dosen berada pada waktu yang sama serta kemungkinan besar dari berbagai posisi (Fenton \& Watkins, 2010).

Menurut (Winataputra, 2008) deskripsi dari akibat reaksi belajar pada perubahan budi pekerti yanh hidup ialah entuk dari kesadaran perilaku, ambisi, tanggapan, atau gabungan dari semuanya dan tingkat belajar seseorang ditentukan oleh suka duka kehidupan yang diperolehnya.

Jeremy Friedman, Ryan Hwang dan tim Trinidad merancang Platform schoology di Washington University. Platforma schoology ialah sebuah jaringan sosial yang difokuskan untuk dipergunakan bagi sekolah maupun perguruan tinggi. Platforma schoologi juga berfokuskan pada kolaborasi yang memungkinkan penggunanya dalam hal membuat, mengola, dan berbagai hal akademis. Nama lain dari schsoology ialah sistem manajemen (LMS) dan juga sitem manajemen khusus (CMS).

Proses yang memberi semangat, arah, dan kegigihan perilaku merupakan deskripsi dari kata motivasi. Seseorang yang mempunyai perilaku yang penuh dengan energi, terarah dan tahan lama merupakan arti dari perilaku yang mempunyai motivasi. Pada dasarnya dua hal yang saling mempengaruhi ialah motivasi dan belajar. Alasannya dikarenakan dalam hal belajar motivasi akan mendorong perilaku seorang mahasiswa agar mempunyai rasa lebih bersemangat dan mempunyai rasa senang yang pada akhirnya membuat mahasiswa memperoleh prestasi yang jauh lebih baik.

Self Efficacy, Locus of Control, Goal Orientation, Effort, Interest, Self Regulation, Self Esteem, Sense of self as learner merupakan hal yang mempengaruhi motivasi belajar dari dalam atau internal. Home Support, Assessment Practice, Peer Culture, Pedagogy, Curriculum dan School Ethos ialah hal yang mempengaruhi motivasi belajar dari luar atau eksternal (Wayne \& Ruth, 2003).

Adanya proses belajar merupakan bentuk dari pemahan. Sedangkan pengertian dari pemahaman itu tersendiri ialah salah satu bentuk dari hasil belajar. Pemahaman juga bisa 
diartikan sebagai menguasai suatu hal dengan pikiran. Dengan pengertian pemahaman yang sudah dipaparkan bahwasannya belajar juga berarti harus paham secara mental. Pemahaman sangat penting bagi seorang mahasiswa alasannya karena dengan memahami pemahaman mahasiswa akan tau apa tujuan akhir dari setiap pembelajaran. Maka dari itu mahasiswa dituntut untuk meningkatkan pemahamannya agar saat proses belajar terasa menyenangkan dan ilmu yang di dapat lebih akurat.

Model pembelajaran problem based lerarning dan blended learning ini diharapkan bisa diaplikasikan dalam mata kuliah Algoritma pemprogaman untuk mengarahkan mahasiswa agar lebih aktif dan bekerja secara kelompok dari suatu masalah kemudian bisa diterapkan dalam bentuk kode program. Diharapkan juga dengan permasalahan yang ada bisa membuat suatu kode program yang akan menambah keterampilan mahasiswa dalam mata kuliah Algoritma Pemrograman.

\section{METODE}

\section{A. Model Blended Learning}

Desain eksperimen semu (quasi-experiment) dengan non equivalent control group design merupakan metode yang digunakan dari penelitian ini

Pada penelitian ini kelompok eksperimen memanfaatkan modelblended learning $\left(X_{1}\right)$ sedangkan kelompok kontrol menggunakan konvesional $\left(X_{2}\right)$.

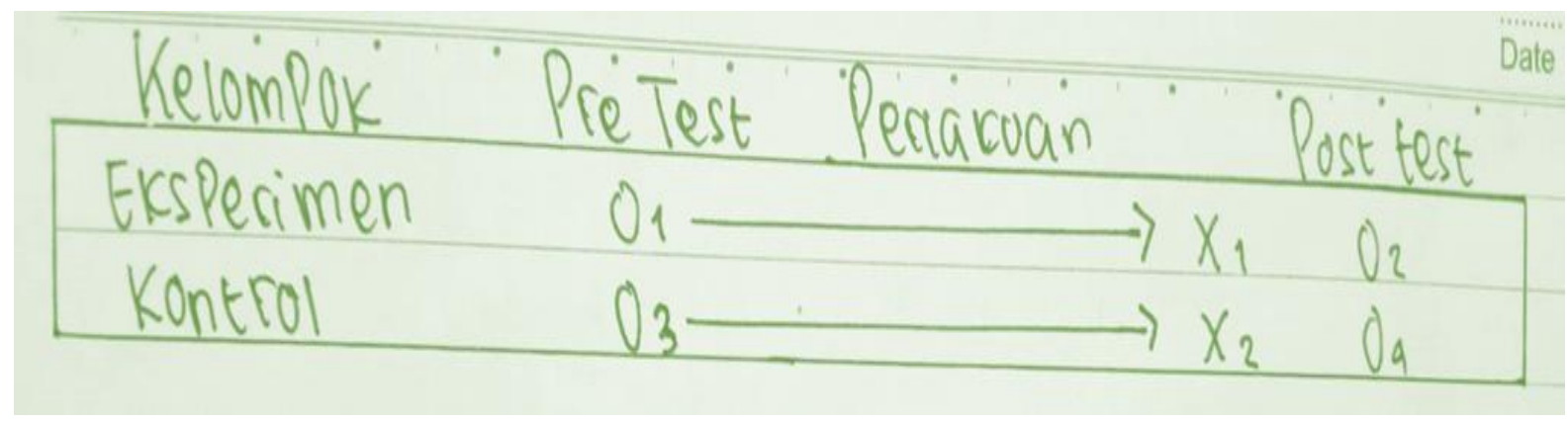

Gambar 1. Desain Penelitian 
Ketecangan:

$\mathrm{O}_{1}$ : Kemampuan kelompok eksperimen sobelum diberikan perlakuan

$\mathrm{O}_{2}$ : Kemampuan kelompok exsperimen setelah diberikan perlakoan

$x_{1}$ : Pertacuan dengan Pembelajacan model Blended learning

$x_{2}$ : Peclacuan dengan pembelajacan model convesional

$\mathrm{O}_{3}$ : Kemampuan kelompok kontfol sebelum diberican peclakuan

$\mathrm{O}_{4}$ : Kemampuan kelompok kontrol setelah diberican perlacuan

Pada kelompok eksperimen dan kelompok kontrol untuk mengukur efektivitas model blended learning maka dilaksanakannya pre test dan post tes. Cara melihat efektivitas dari model blended learning dengan cara melihat total pre test dan post pada kelompok kontrol dan kelompok eksperimen. Data dari penelitian ialah data skor dari motivasi dan tingkat pemahaman.

Dapat mengetahui motivasi dan tingkat pemahaman para mahasiswa dengan menggunakan model blended learning merupakan tujuan dari penelitian ini. Untuk dilakukannya pengujian efektivitas makan dilakukanlah percobaan yang disrumuskan dalam hipotesis penelitian. Dengan menggunakan uji-t pada uji statitik parametik kita dapat memeriksa signifikansi perbedaan mead pada lebih dari dua kelompok yang berlainan akibat dari beberapa perlakuan pengguna suatu variabel bebas. Sebelum melakukan pengujian, data yang diperoleh harus memiliki petisi dilakukannya dengan parametik tes diantaranya yaitu berdistribusi norma dan sama.

\section{B. Pengembanagan Modul}

Jenis observasi yang digunakan adalah Research and Development yang sering disebut sebagai penelitian pengembangan. Tahapan penelitian yang digunakan mengacu pada Thiagarajan (1974), yang dikenal dengan 4D yaitu define, design, develop, dan disseminate. Tetapsi, untuk tashap disseminate tidak dilakukan dalam penelitian ini dikarenakan dependensi waktu. 
HASIL

A. Model Blended Learning

Hasil analisis hipotesis 1 memanfaatkan data motivasi akhir kelas eksperimen dan kontrol. Untuk menguji hipotesis 1 maka digunakanlah uji t dengan taraf signifikan 0,05 .

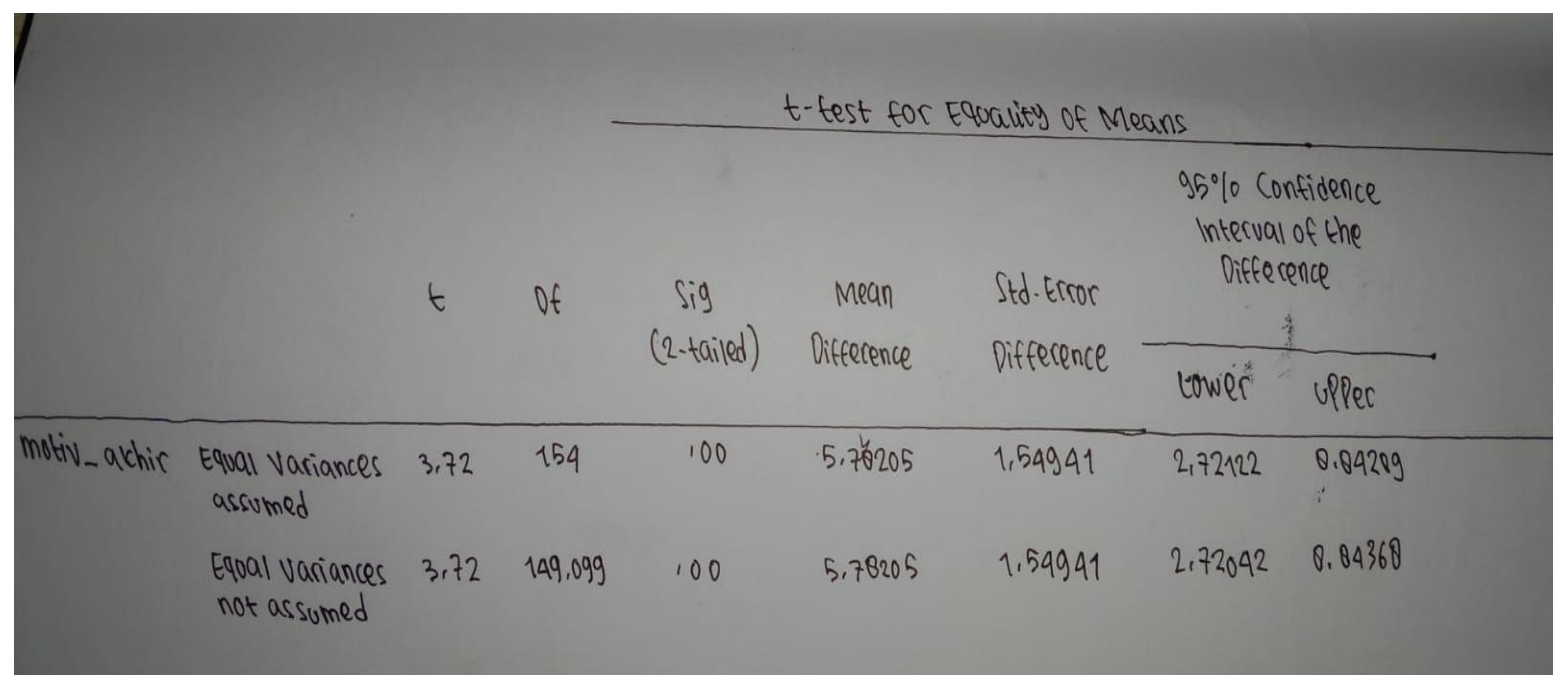

Output Independent Samples Test Motivasi Belajar

Kelas Eksperimen dan Kelas Kontrol

Hasil dari uji hipotesis diatas adalah motivasi akhir kelas eksperimen terhadap kelas kontrol memberikan nilai signifikansi $0,000<$ signifikansi 0,05 . maka rata-rata fari perbedaan motivasi antara kelas eksperimen dan kelas kontrol yaitu 5,782 . maka dapat di simpulkan yaitu bahwasannya terdapat perbedan motivasi belajar pada mahasiswasetelah mengikuti model pembelajaran blanded learning dengan mahasiswa yang mengikuti pembelajaran model konvesional.

Perbedaan dari rata-rata motivasi akhir bealajar mahasiswa antara kelas eksperimen dan kelas kontrol disajikan dapat dilihat di bawah ini. 


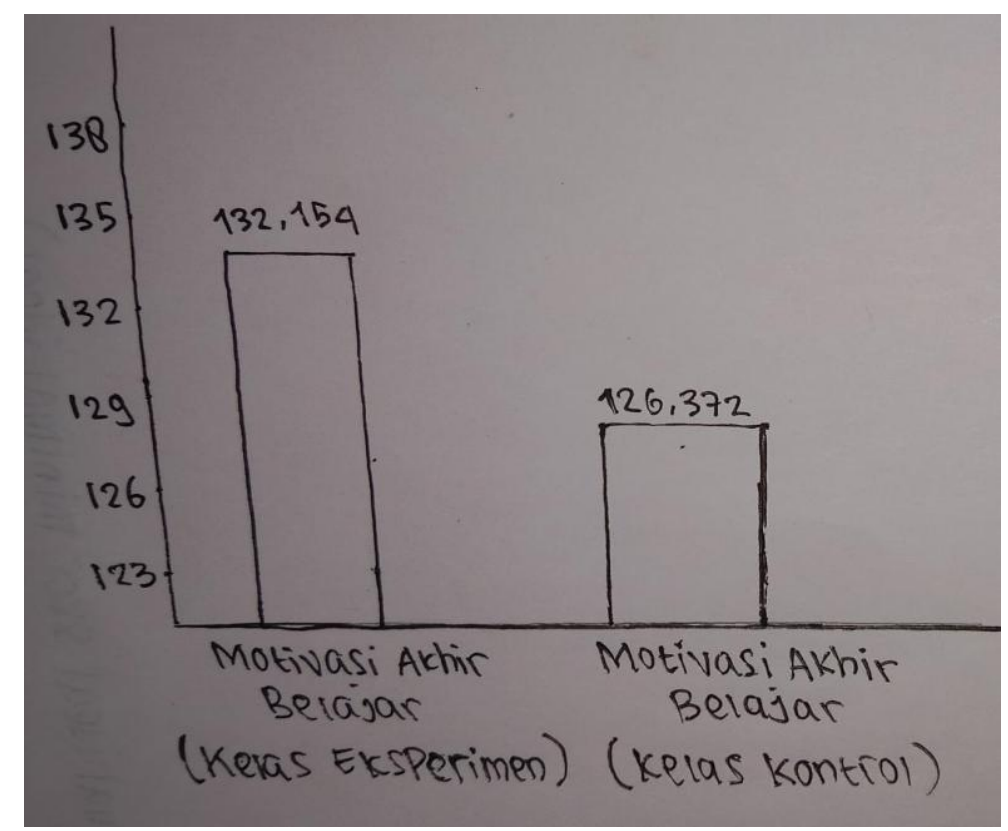

Gambar 2. Rata-Rata Motivasi Akhir Belajar dari Kelas Eksperimen dan Kontrol

Perhitungan yang menggunakan uji t pada hasil analisis hipotesis 2 pada tingkat pemahaman dari kelas eksperimen dan kelas kontrol menggunakan data pottest.

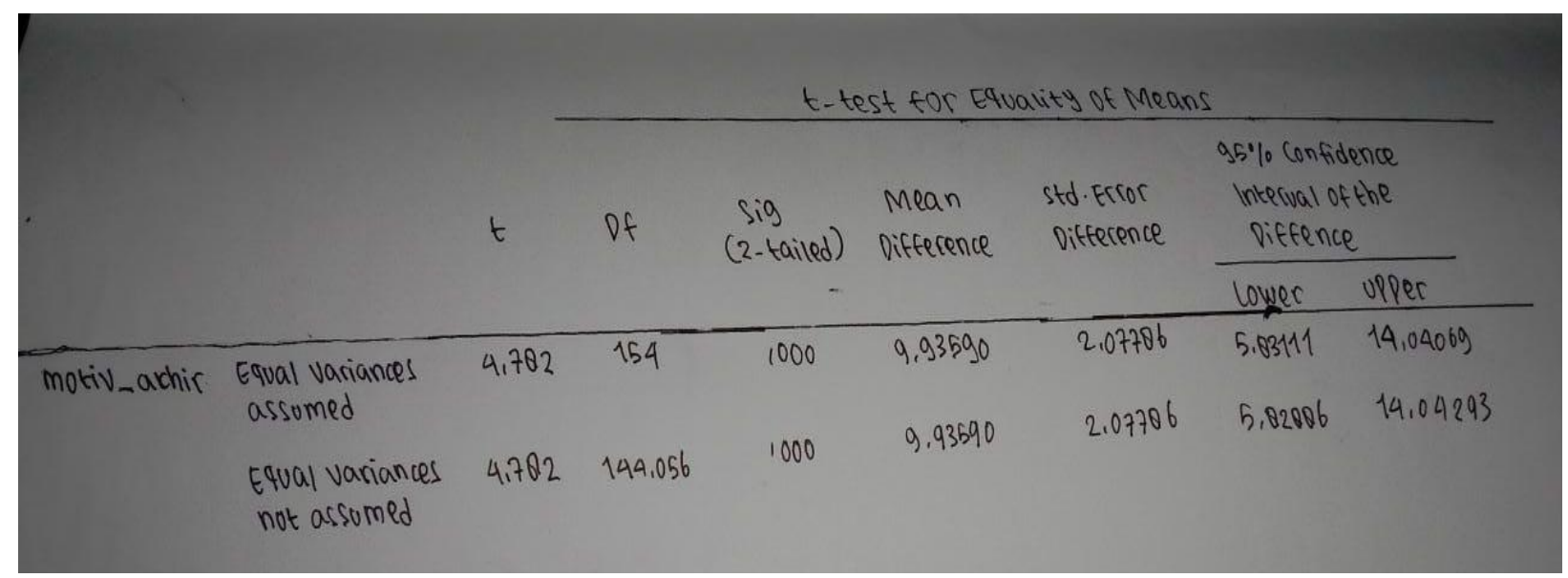

\section{Output Independent Samples Test Tingkat Pemahaman}

\section{Kelas Eksperimen dan Kelas Kontrol}

Hasil dari analisis diatas yaitu bahwa pottest kelas eksperimen terhadap kelas kontrol memberikan nilai signifikansi $0,000<$ signifikansi 0,05. Maka dari itu terdapat sebesar 9,935 pada perbedaan rata-rata pottest dari kelas eksperimen dan kelas kontrol. Dan dapat disimpulkan bahwa perbedaan dari tingkat pemahaman mahasiswa setelah mengikuti pembelajaran model blended learning dengan mahasiswa yang mengikuti pembelajaran model konvesional. 
Perbedaan dari rata-rata pottest mahasiswa anatar kelas eksperimen dan kontrol disajikan pada gambar di bawah ini.

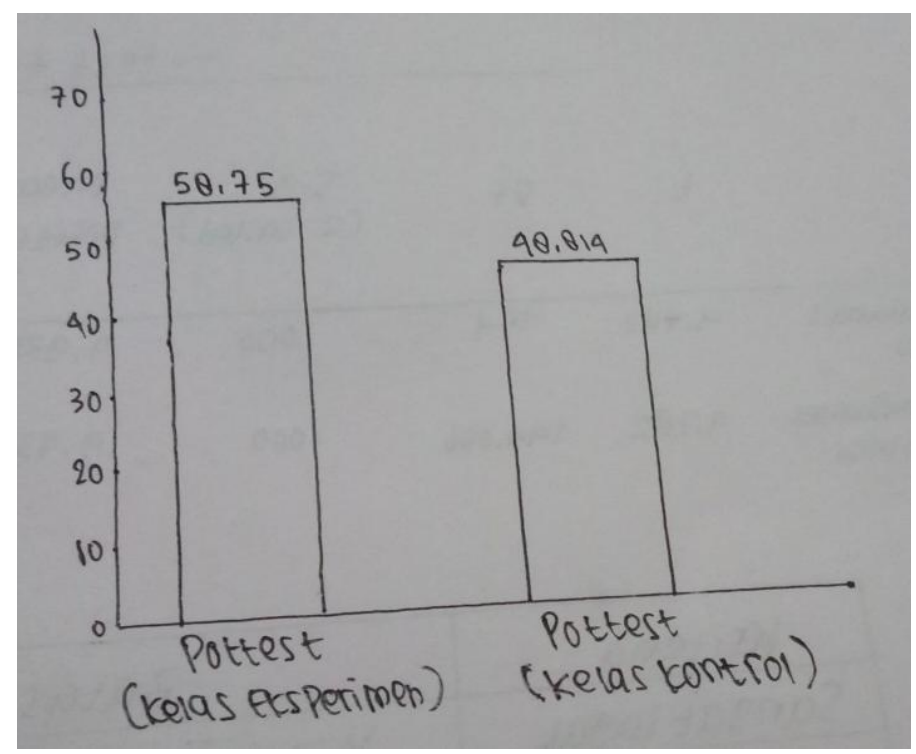

Gambar 3. Rata-Rata Posstest pada Kelas Eksperimen dan Kontrol

Hasil dari hipotesis 3 menggunakan data skor motivasi belajar sebelum dan sesudah pembelajaran blended learning. Pengujian menggunakan uji t paired samples test. Dengan menggunakan taraf siginifikasnsi 0,05. Maka diperoleh bahwa terdapat peningkatan motivasi belajar mahasiwa akibat penerapan pembelajaran blended learning, dengan nilai signifikansi $0,000<$ nilai signifikansi 0,05 .

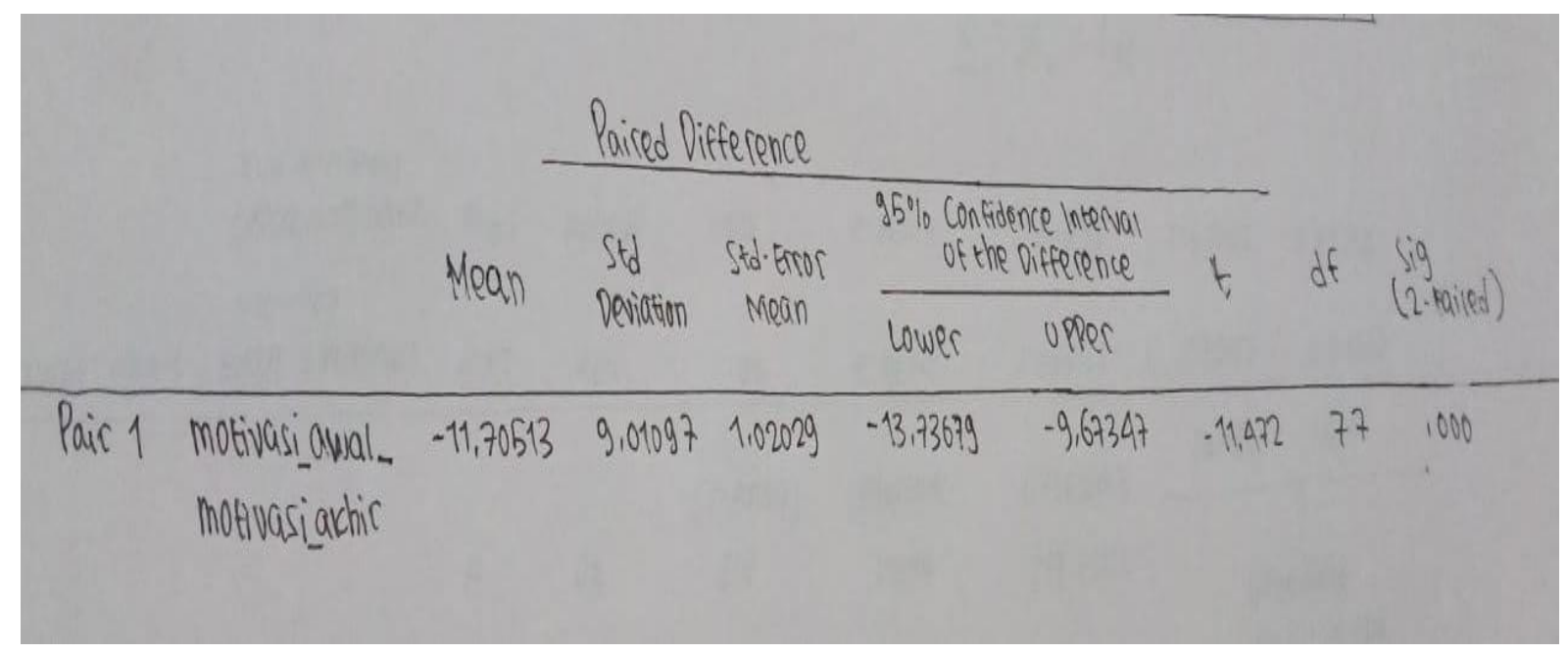

Output Paired Samples Test Untuk Hipotesis 3 


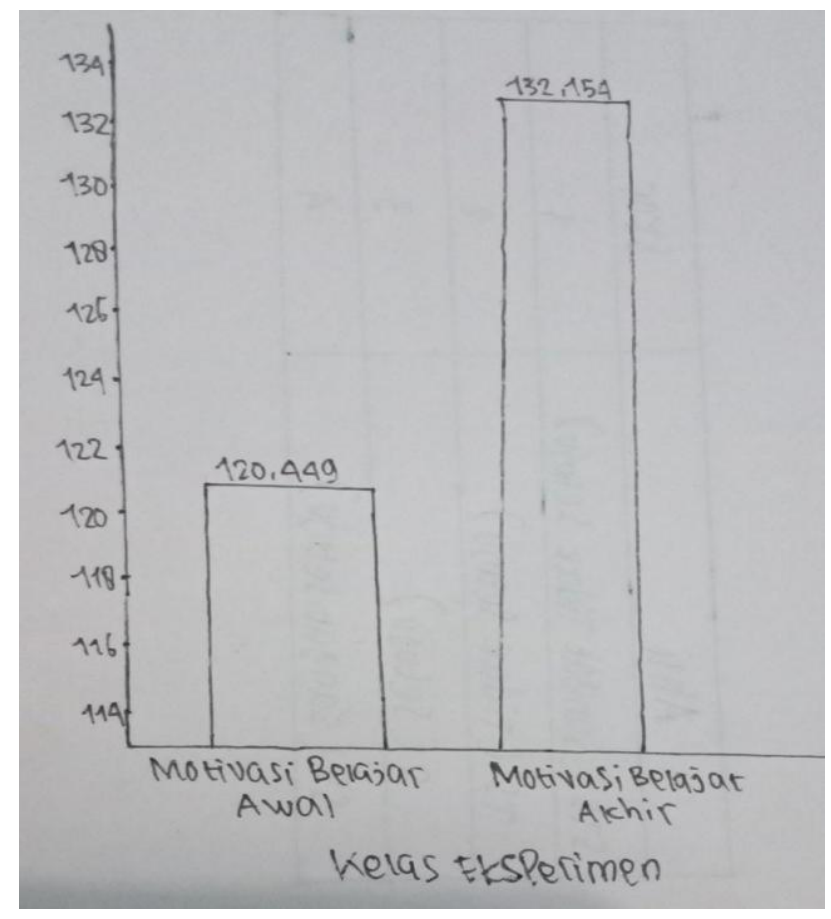

Gambar 4. Rata-Rata Motivasi Belajar Sebelum dan Sesudah Penerapan Blended Learning

Berdasarkan gambar diatas dapat dilihat rata-rata skor dari motivasi belajar yang belum diukur dengan menggunakan pembelajaran blended learning sebesar 120,449. Sedangkan rata-rata dari yang sudah diberikan pembelajaran dengan menggunakan blended learning adalah sebesar 11,705 point. Maka dari itu akibar dari penerapan juga dapat dilihat dari tabel beikut ini.

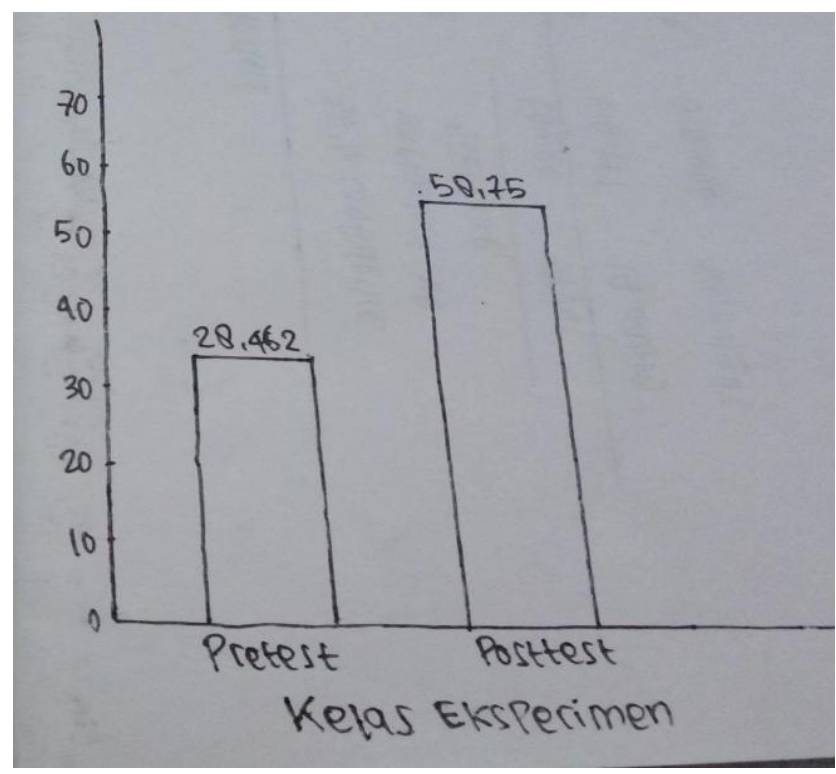

Gambar 5. Rata-Rata Tingkat Pemahaman Sebelum dan Sesudah Penerapan Blended Learning 
Maka dapat disimpulkan bahwa rata-rata nilai pada tingkat pemahaman sebesar 28,462 merupakan skor yang didapat sebelum pembelajaran. Sedangkan nilai rata-rata sebesar 58,750 merupakan skor dari setelah diberikannya pembelajaran blended learning. Dari kedua angka tersebut dapat dilihat bahwa adanya peningkatan sebesar 30,288 point.

Berdasarkan hasil hipotesis satu terdapat perbedaan motivasi belajar mahasiswa. Nilai signifikansi sebesar 0,000 lebih kecil dari 0,05 merupakan nilai setelah mengikuti pembelajaran yang memakai pembelajaran model dean pembelajaran model konvesional. Sedangkan nilai sebesar 126, 371 adalah nilai mahasiswa kelas kontrol pada rata-rata skor motivasi belajar. Mahasiswa yang keaktifannya meningkat pada partisipasi dan perhatian pada saat proses pembelajaran adalah salah satu hal yang dapat dilihat adanya perbedaan dari peningkatan motivasi.

Berdasarkan hasil hipotesis dua terdapat perbedaan seperti dimana nilai signifikan yaitu sebesar 0,000 lebih kecil dari 0,5 yang terjadi pada mahasiswa setelah mengikuti pembelajaran model konvesional dengan pembelajaran model blended learning. Dengan adanya media online yang berbasis web sangat membantu para mahasiswa dalam meningkatkan kualitas belajara, karena web dapat menyediakan soal beserta lengkap dengan jawabannya. Maka dari itu mahasiswa dengan mudah apa yang menjadi kesulitan dalam mengetahui sebuah materi.

Berdasarkan hasil hipotesis tiga akibat penerapan pembelajaran blended learning dimana kenaikan pada motivasi belajar mahasiswa yaitu nilai signifikansi sebesar blended learning $0,000<0,05$. Pada pembelajaran dapat memadukan antara tatap muka dengan online. Hal ini dapat memunculkannya interaksi tidak hanya mahasiswa dengan dosen tetapi melainkan juga interaksi antar saling mahasiswa.

Berdasarkan hasil hipotesis empat akibat dari penerapan pembelajaran model blended learning ialah sebesar 28,462. Banyaknya sumber belajar yang bisa di akses tanpa adanya sumber batasan merupakan contoh dari kelebihan pembelajaran blended learning. Tidak hanya itu, pelaksanaan pembelajaran juga sangat efesien karena pemberian materi yang mandiri dan memerlukan penjelasan khusus.

B. Pengetahuan Modul 
Sesuai dengan penelitian pengembangan, maka hasil terfokus pada hasil evaluasi atau masukan-masukan pada saat menyusun modul. Tujuan uji coba pada produk tahapan pengembangan adalah agar adanya variasi prototype dari modul yang telah dibuat sampai pada tahap design. Tingkatan ini terdiri dari validasi modul dan uji coba modul.

Validasi modul dilakukan oleh dua pakar materi dan dua pakar media. Hal yang dilakukan seperti memberikan sebuah angket, di dalam angket tersebut terdapat beberapa aspek tentang yang diujikan dari modul. Panduan memperbaikan rancangan modul yang telah dibuat merupakan atas pendapat dan saran yang telah diperoleh dari pakar.

Selanjutnya dilakukan revisi dari hasil penilaian dan masukan para pakar. Kemudian, dilakukan eveluasi melalui uji coba modul pada subjek yang sesungguhnya, uji coba pertama terbatas hanya pada 5 mahasiswa saja. Dilakukan revisi modul berdasarkan masukan dari hasil uji coba utama yang melibatkan 29 mahasiswa prodi Pendidikan Matematika.

Tabel 1. Aturan Penskoran Angket Validasi

\begin{tabular}{|c|c|}
\hline Ahli & Skor \\
\hline STS (Sangat Tidak Setuju) & 1 \\
\hline TS (Tidak setuju) & 2 \\
\hline S(Setuju) & 3 \\
\hline SS (sangat setuju) & 4 \\
\hline
\end{tabular}

Rumus rata-rata yang digunakan adalah sebagai berikut
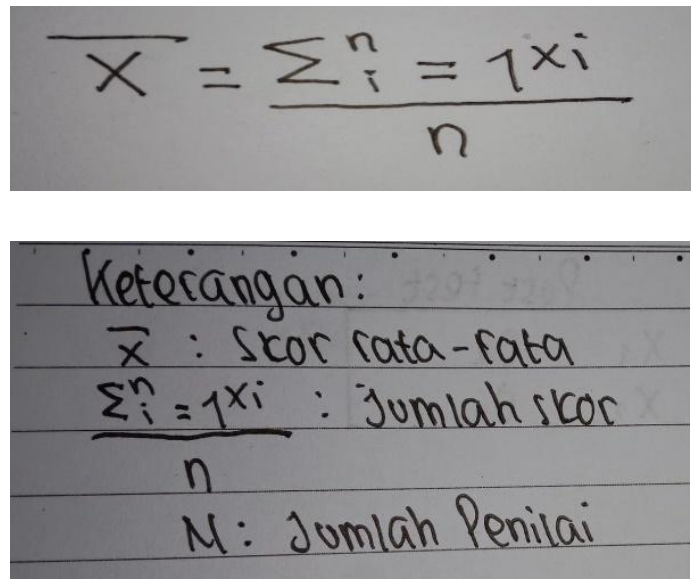
Data angket dirangkum dalam bentuk tabel.

Kriteria dan batas nilai serta perhitungan skor angket menurut Mardapi (2008) adalah sebagai berikut.

Tabel 2. Kriteria dan Batas Nilai
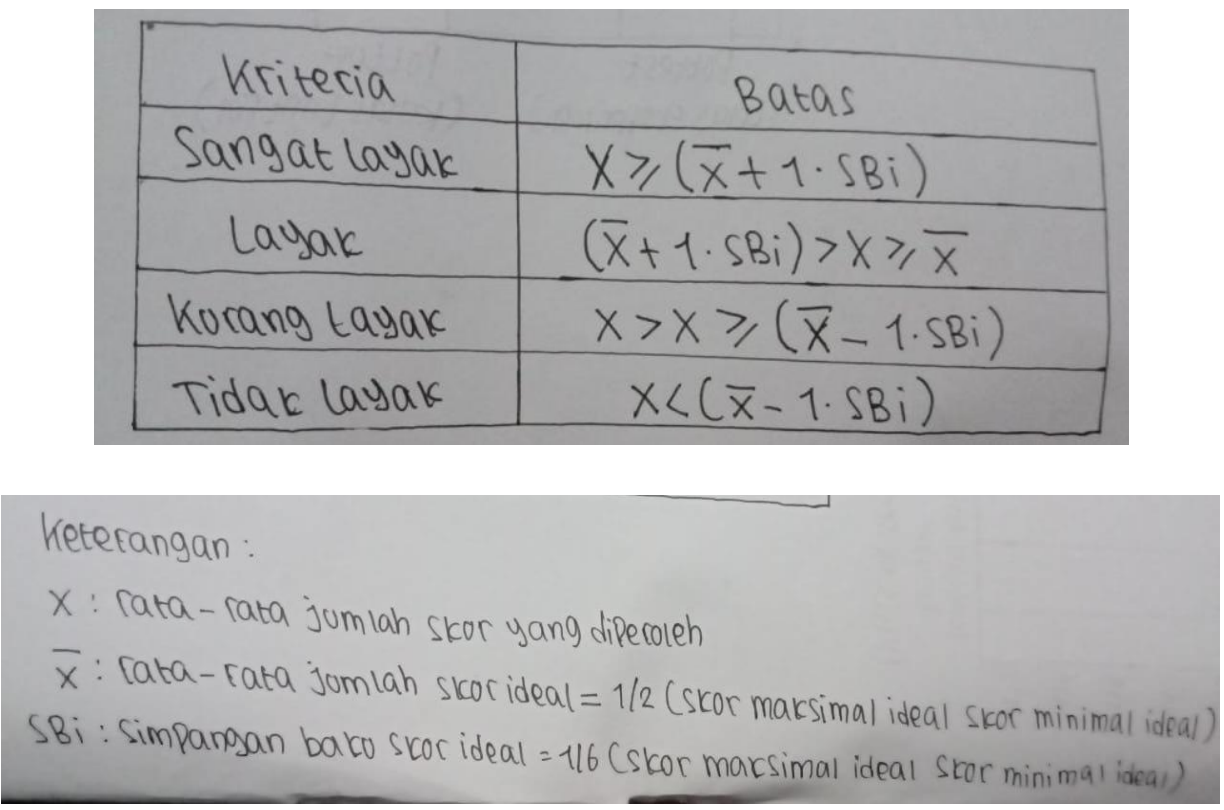

Adapun hasil validasi ahli materi disajikan dalam Tabel 3 berikut.

Tabel 3. Hasil Perhitungan

Nilai Rerata Ahli Materi

\begin{tabular}{|c|c|c|c|}
\hline No & Aspek Penilaian & Rerata Skor & Kategori \\
\hline $\mathbf{1}$ & Self Instruction & 61 & \\
\hline $\mathbf{2}$ & Self Contained & 4 & \\
\hline $\mathbf{3}$ & Stand Alone & 3 & \\
\hline $\mathbf{4}$ & Adaptive & 3.5 & \\
\hline $\mathbf{5}$ & User Friendly & 9.5 & \\
\hline $\mathbf{6}$ & Kemutakhiran Isi & 19 & Layak \\
\hline $\mathbf{7}$ & Manfaat & 24 & \\
\hline \multicolumn{2}{|c|}{ Total keseluruhan Rerata Skor penilaian } & $\mathbf{7 5}$ & \\
\hline
\end{tabular}


Skor dari rata-rata tersebut dikatakan sangat layak. Karena nilai berada pada $X \geq 105$. Dari total keseluruhan materi sebesar 124. Jika diubah ke bentuk persentase maka hasilnya adalah $88,57 \%$, nilai tersebut didapat dari rata-rata angket makar materi.

Pada penilaian ahli media aspek penilain pada grafika rata-rata skornya yaitu 106,5 dan aspek penilaian pada penyajian rata-rata skornya yaitu 40. Dan total dari keseluruhan rata0rata skor penilaian adalah 146,5 (termasuk ke dalam kategori layak).

Begitu juga skor rata-rata pada penilaian pakar media dikatakan sangat layak karena berada pada rentang skor $X \geq 138$ dari tital keseluruhan 146,5 . Nilai 79,61\% merupakan nilai rata-rata yang didapat dari angket pkar media jika telah diubah ke dalam bentuk persen.

Kemudian dilakukan uji coba produk pada mahasiswa prodi pendidikan matetmatika yang mengambil mata kuliah Algoritma dan Pemprogaman. Kegiatan pengujian dilakukan dengan mahasiswa menggunakan modul dalam proses pembelajaran di kelas kemudian mengisi angket evaluasi. Mhasiswa yang terlibat dalam pengisian angket berjumlah 5 orang pada uji coba terbatas dan 29 mahasiswa pada uji coba utama. Setelah uji coba terbatas, modul direvisi kemudian dilakukan uji coba utama.

Pada hasil perhitungan nilai pengguna pada uji coba terbatas aspek penilain pada tampilan rata-rata skornya yaitu 19, sedangkan pada penyajian materi rata-rata skornya yaitu 39 dan aspek penilaian dari manfaat rata-rata skornya adalah 17. Dan total pada keseluruhan rata-rata skor adalah 75 (termasuk ke dalam kategori layak).

Pada hasil perhitungan nilai pengguna uji coba utama aspek penilaian pada tampilan rata-rata skornya adalah 20, pada penyajian rata-rata skornya adalah 42 dan pada aspek penilaian manfaat rata-rata skornya adalah 19. Dan total dari keseluruhan rata-rata skor penilaian adalah 81 (termasuk kedalam kategori yang sangat layak).

Total keseluruhan rata-rata skor penilaian pengguna pada uji coba terbatas sebesar 75 yang berada pada rentang skor $76>X \geq 63$ berdasar tabel kriteria dan batas nilai. Skor tersebut termasuk kategori layak, sedangkan jumlah semua rata-rata skor penilaian pengguna pada uji coba utama sebesar 81 yang berada pada rentang skor $X \geq 76$, yang termasuk dalam kategori sangat layak. Nilai $75 \%$ dan $81 \%$ merupakah hasil dari nilai uji coba terbatas dan nilai uji coba utama jika di ubah ke dalam bentuk persen.

Hasil validasi kelayakan dari ahli materi, ahli media, dan uji coba pada pengguna mahasiswa dapat disajikan dalam grafik berikut ini. 


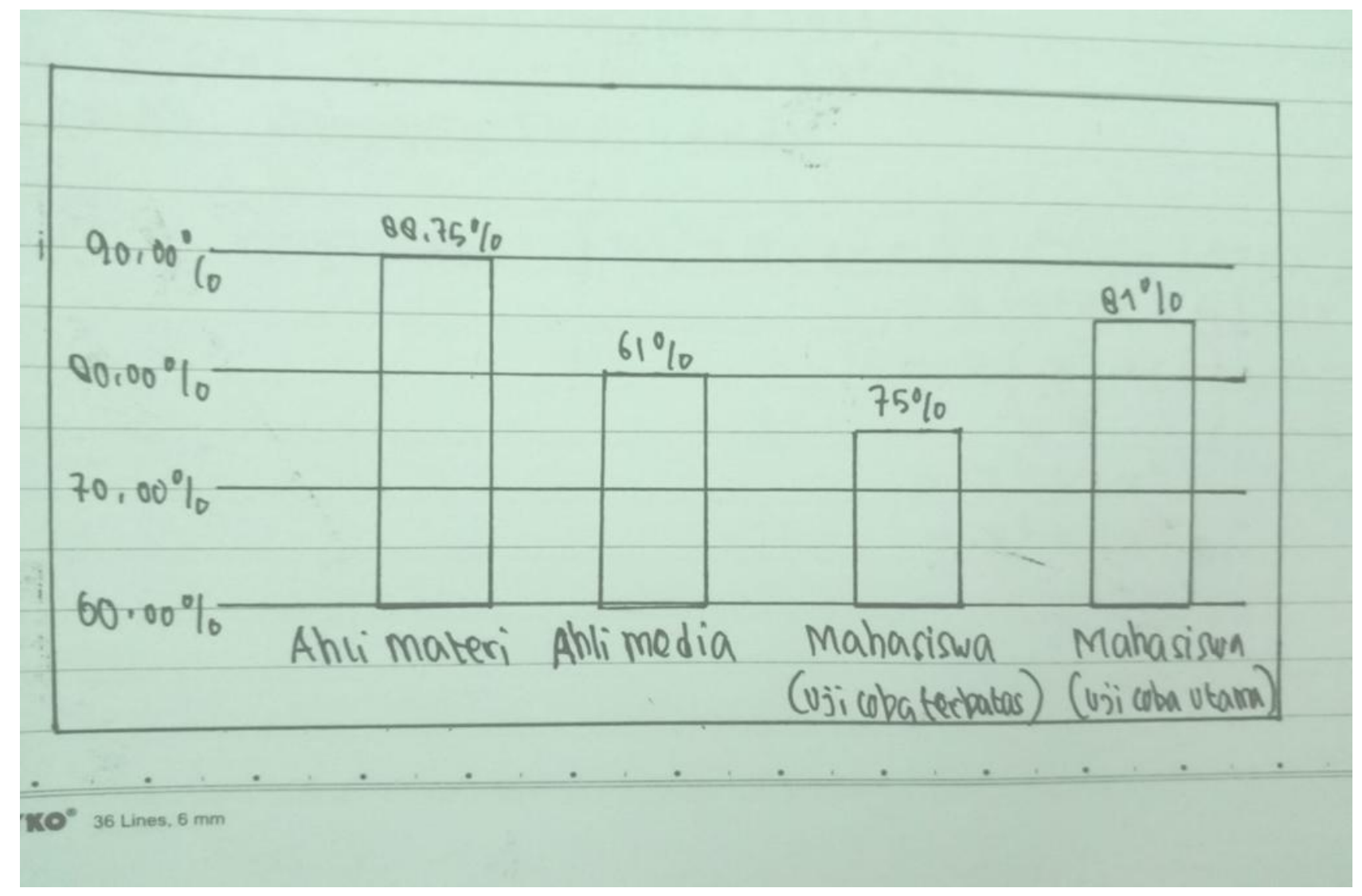

Gambar 6. Grafik Persentase Kelayakan Modul Algoritma dan Pemprogaman

Berdasarkan pembahasan yang dipaparkan diatas, bahwasannya menujukkan modul sangat layak pada pengujian ahli materi, ahli media, dan mahasiswa. Hal lain yang juga dapat disimpulkan adalah dengan adanya modul algoritma dan pemrograman dapat membantu baik pada dosen maupun pada mahasiswa pada saat kegiatan pembelajaran prodi pendidikan matematika. 


\section{KESIMPULAN}

Berdasarkan penjelasan dan data di atas maka dapat disimpulkan bahwa terdapat perbedaan yang signifikan terhadap motivasi belajar dan tingkat pemahaman mahasiswa yang telah menggunakan model blended learning dengan kelas yang menggunakan model konvesional pada mata kuliah algoritma dan pemrograman. Tingkat pemahaman mahasiswa memiliki perbedaan yang signifikan antara kelas yang menggunakan model blended learning dengan kelas yang menggunakan model konvesional. Motivasi belajar mahasiswa mengalami kenaikan secara signifikan dikarenakan penerapan model blended learning dan juga tingkat pemahaman mahasiswa mengalami kenaikan karena penerapan model blended learning .dan berdasarkan uraian dan data di atas, maka disimpulkan bahwa yaitu hasil akhir produk yang dikembangkan berupa modul mata ilmu pemrograman yang sesuai dengan karakteristik mahasiswa prodi pendidikan matematika serta modul yang dihasilkan memiliki kriteria sangat layak yang berdasarkan pada hasil validasi ahli materi, ahli media, dan uji coba mahasiswa. Hasil validasi modul oleh ahli media yaitu $79.61 \%$, dan uji coba utama pada mahasiswa memperoleh nilai $81 \%$.

\section{DAFTAR PUSTAKA}

Abdul, K. (2012). Algoritma dan Pemprograman menggunakan java. Yogyakarta : Andi offset

A.G. (2016). Learning Sebagai Peran Teknologi Informasi Dalam Modernisasi Pendidikan. Jurnal Sist Inf Univ Suryadarma

Dharmawati, W., \& Oktarika, D. (2019) Pengembanagan Media Pembelajaran Berbasis Multimedia Interaktif untuk Guru Ipa Di Sekolah. Jurnal Pendidikan Informatika dan Sains Hamadin, dkk. (2015). Pengembanagan Media Pembelajaran Interaktif Berbasis Tik Dengan Pendekatan Saintifik. Jurnal fkip Unila

Laili, I. (2019). Efektivitas Pengembangan E-Modul Project Based Learning Pada Mata Pelajaran Instlasi. Jurnal Ilmiah Pendidikan dan Pembelajaran

Pribadi, A. B. (2009). Model Desain Sistem Pembelajaran. Jakarta : Dian Rakyat 
Sanjaya, W. (2009). Strategi Pembelajaran Bereorentasi Standar Proses Pendidikan. Jakarta : Penada Media Grup

Sudarman. (2016). Problem Based Learning : Suatu Model Pembelajaran untuk Mengembangkan dan Meningkatkan Pemecahan Masalah. Jurnal Pendidikan Inovatif

Suparman . (2015). Peningkatan Kemandirian Belajar dan Minat Belajar Mahasiswa Mata Kuliah Elektronika Analog dengan Pembelajaran PBL. Jurnal Pendidikan Teknologi dan Kejuruan

Sulistyyohati, A. (2020). Pengukuran Learning Pada Mhasiswa Sebagai Upaya Penerapan Pembelajaran Jarak Jauh. Jurnal Pendidikan Informatika

Syaharuddin, S., \& Mandailina, V. (2017) Pengembangan Modul Pemprograman Komputer Berbasis Matlab. Jurnal Teori dan Aplikasi Matematika.

Zaenal, Abidin, Motivasi dalam strategi pembelajaran dengan pendekatan ARCS. Jurnal Fakultas Agama Islam Universitas Muhammadiyah Surakarta. 


\section{Artikel revisi sai \\ by Sai Sai}

Submission date: 28 -Oct-2021 04:03PM (UTC+0700)

Submission ID: 1686416101

File name: ARTIKEL_ALGORITMA_DAN_PEMROGRAMAN_SA_I_FRIDA_REJEKI.pdf (741.07K)

Word count: 3138

Character count: 20471 


\title{
KEEFISIENAN MODEL BLENDED LEARNING TERHADAP MOTIVASI DAN TINGKAT PEMAHAMAN SERTA PENGEMBANGAN MODUL UNTUK MAHASISWA PADA MATA KULIAH ALGORITMA DAN PEMROGRAMAN
}

\author{
Sa'i Frida Rejeki (0305202056) \\ Program Studi Pendidikan Matematika-2 \\ 16 \\ Fakultas Ilmu Tarbiah dan Keguruan UIN Sumatera Utara \\ Jl. Wiliam Iskandar Pasar V, Medan Estate \\ Email : saifrida651@gmail.com
}

\begin{abstract}
Abstrak
Algoritma adalah suatu metode atau langkah-langkah yang efektif yang telah disusun secara tertulis dan secara berurutan yang berisikan kumpulan perintah untuk menyelesaikan suatu permasalahan yang dimana setelah itu perlu diselesaikan secara sistematis. Analisis tinjauan pada studi pendidikan matematika terhadap artikel atau tulisan yang membahas mengenai Kemampuan Mahasiswa Mata Kuliah Algoritma Pemprogaman ini bertujuan agar mahasiswa memahami lebih dalam tentang algoritma dan pemrogaman. Mata kuliah algoritma dan pemrograman khusus diarahkan untuk mahasiswa agar mahasiswa dapat mengembangkan pengetahuan kognitif dan motorik para mahasiswa terhadap asepek-aspek tertentu. Selain itu, tujuan dari penelitian ini yaitu sebagai bahan ajar modul algoritma dan pemprogaman yang berbasis problem based learning, sebagai pemahaman pembelajaran blended learning dan pembelarajaran konvesional. Jenis penelitian dari model blended learning adalah quasi eksperimental Langkah yang digunakan dari pengembangan modul adalah pendefinisian, perencanaan, pengembangan, dan diseminasi. Dengan studi literatur ini mahasiswa dapat memahami dapat memahami dan lebih mengerti tentang maksud dan tujuan dari mata kuliah algoritma dan pemprograman, seperti contohnya mahasiswa dapat memahami tentang hal konsep serta konstruksi dasar dalam algoritma ke dalam bahasa pemprograman.
\end{abstract}

Kata kunci: Algoritma Pemrograman, Blanded Learning, Modul 


\section{PENDAHULUAN}

Pengembangan dalam bidang pendidikan sudah diatur dalam Undang-Undang Nomor 20 Tahun 2003 Pasal 3 tentang Sistem Pendidikan Naional bahwasannya pendidikan nasional berfungsi dalam mengembangkan kemampuan seseorang dalam rangka mencerdaskan kehidupan bangsa yg memiliki tujuan untuk mengembangkan potensi peserta didik agar menjadi insan yang berguna.

Kemajuan teknologi dan informasi dengan seiring berkembang pesatnya kemajuan teknologi yang mengakibatkan terjadinya perkembangan yang sangat pesat di berbagai bidang ilmu. Dengan adanya kemajuan dari ilmu pengetahuan di berbagai bidang kehidupan tidak lepas dari dalam bidang pendidikan yang membawa perubahan peningkatan terhadap pendidikan. Seperti aplikasi matematika sebagai pendukung bidang ilmu lain juga mengalami perkembangan,misalnya pemprogaman. Di masa yang akan datang perkembangan pendidikan tidak akan lepas dari beberapa faktor yang mempengaruhinya. Dalam situasi inilah dalam bidang pendidikan dan pembelajaran diperlukan adanya suatu pembaruan yang secara terus menerus tanpa adanya perhentian agar pendidikan setiap tahunnya selalu maju. Dengan adanya perubahan yang bertujuan untuk meningkatkan kualitas pendidikan dan pembelajaran sudah termasuk ke dalam contoh dari hasil pendidikan dan pembelajaran.

Deskrpisi dari makna memahami sistem pendidikan nasional ialah landasan penyelenggaran pendidikan dijadikan sebagai pesan moral dan tercapainya cita-cita perjuangan bangsa Indonesia sebagai sarana. Sedangkan deskripsi dari tujuan penelitian ialah menyuplai tenaga kerja dengan kebutuhan lapangan kerja seperti memiliki pengetahuan yang luas serta memiliki keterampilan yang unik serta menyuplai tenaga kerja yang dapat menerima dan beradaptasi dalam perkembangan teknologi. Dalam prosesnya juga perlu menumbuhkan pada seluruh mahasiswa tentang pentingya keterampilan dan kemajuan informasi, sikap independen, dan rasa harapan untuk keberhasilan dalam karir sepanjang hayat.

Pembelajaran yang tersusun terdapat beberapa elemen yang satu saling mendukung. Seperti yang telah dikemukakan oleh Pribadi (2019) bahwasannya pengkajian dapat dipandang sebagai suatu sistem dengan elemen-elemen yang saling terkait agar tercapainya penguasaan wawasan, kemahiran, dan tindakan oleh peserta didik yang diperlukan untuk melakukan suatu kegiatan. 
Mahasiswa merasakan ada kekurangan pada saat belajar yang diperoleh dari internet,seperti yaitu kurangnya tersedia entitas tertentu pada bab serta adanya variasi pernyataan dari berbagai sumber. Sedangkan, materi ajar lain dari dosen atau buku konvesional, yaitu buku berupa modul yang telah dikembangkan oleh dosen sebagai fasilitas mata kuliah algoritma pemprogaman belum ada.

Kemampuan mahasiswa dalam memecahkan suatu permasalahan sangat rendah. Salah satu penyebabnya yaitu kurangnya mendalami entitas yang disampaikan oleh dosen. Hanya beberapa mahasiswa saja yang rajin dalam hal mencari sumber pembelajaran yang lain. Selain itu mahasiswa hanya akan menyalin apa yang disampaikan oleh dosen tanpa memhami alur dan fungsi dari kode-kode didalamnya. Contohnya adalah program dan penyelesaiannya, serta latihan soal untuk dipraktikkan ke mahasiswa.

Masalah yang terjadi pada mahasiwa tersebut dapat diberikan resolusi, salah satunya adalah dengan mengimplementasikan versi pengkajian problem based learning. Menurut Sudarman (2014) suatu pendekatan pengkajian yang menggunakan masalah dunia nyata sebagai konteks bagi peserta didik agar memiliki pola pikir yang kritis dan memliki keterampilan dalam memecahkan suatu hal masalah merupakan deskripsi dari versi pengkajian based learning. Menurut Sanjaya (2009) Karakteristik dalam model pengkajian based learning adalah kegiatan pengkajian yang dilakukan mahasiswa tidak hanya mendengarkan penjelasan dari dosen, menjiplak, dan mengingat materi tetapi mahasiswa harus andal dalam berkomunikasi, berpendapat,dan mengolah data sesuai dengan permasalahan yang diajukan oleh dosen. Hal ini sejalan dengan kompendium di perguruan tinggi yaitu lebih berpusat ke mahasiswa dan dosen hanya sebagai penyedia.

\section{PEMBAHASAN}

Dalam partikulasi mata kuliah khususnya dalam metode pendidikan seperti sistem pada belajar mengajar metode pembelajaran yang dilakukan dosen yaitu dengan memantau penggunaan dari model pembelajaran apakah sesuai dengan mata kuliah yang diajarkan.Mutu dan hasil belajar dipengaruhi oleh pemilihan model pembelajaran yang akan digunakan. Menuntut adanya peningkatan, pembaruan, dan peralihan sepanjang masa merupakan suatu sistem mempelajaran. 
Dosen menyediakan informasi, bahan bacaan, dan materi kuliah untuk mahasiswa dengan menggunakan teknologi komputer untuk mengakses internet. Beberapa dosen memungkinkan mahasiswa untuk berinteraksi satu sama lain dengan menggunakan teknologi komunikasi asynchronous dan synchronous. Komunikasi asynchronous dideskripsikan sebagai tugas yang berlangsung di waktu dan posisi yang berbeda (Fenton \& Watkins, 2010). Komunikasi synchronous dideskripsikan bagaikan tugas yang terjadi secara nyata, dimana mahasiswa dan dosen berada pada waktu yang sama serta kemungkinan besar dari berbagai posisi (Fenton \& Watkins, 2010).

Menurut (Winataputra, 2008) deskripsi dari akibat reaksi belajar pada perubahan budi pekerti yanh hidup ialah entuk dari kesadaran perilaku, ambisi, tanggapan, atau gabungan dari semuanya dan tingkat belajar seseorang ditentukan oleh suka duka kehidupan yang diperolehnya.

1

Jeremy Friedman, Ryan Hwang dan tim Trinidad merancang Platform schoology di Washington University. Platforma schoology ialah sebuah jaringan sosial yang difokuskan untuk dipergunakan bagi sekolah maupun perguruan tinggi. Platforma schoologi juga berfokuskan pada kolaborasi yang memungkinkan penggunanya dalam hal membuat, mengola, dan berbagai hal akademis. Nama lain dari schsoology ialah sistem manajemen (LMS) dan juga sitem manajemen khusus (CMS).

Proses yang memberi semangat, arah, dan kegigihan perilaku merupakan deskripsi dari kata motivasi. Seseorang yang mempunyai perilaku yang penuh dengan energi, terarah dan tahan lama merupakan arti dari perilaku yang mempunyai motivasi. Pada dasarnya dua hal yang saling mempengaruhi ialah motivasi dan belajar. Alasannya dikarenakan dalam hal belajar motivasi akan mendorong perilaku seorang mahasiswa agar mempunyai rasa lebih bersemangat dan mempunyai rasa senang yang pada akhirnya membuat mahasiswa memperoleh prestasi yang jauh lebih baik.

Self Efficacy, Locus of Control, Goal Orientation, Effort, Interest, Self Regulation, Self Esteem, Sense of self as learner merupakan hal yang mempengaruhi motivasi belajar dari dalam atau internal. Home Support, Assessment Practice, Peer Culture, Pedagogy, Curriculum dan School Ethos ialah hal yang mempengaruhi motivasi belajar dari luar atau eksternal (Wayne \& Ruth, 2003).

Adanya proses belajar merupakan bentuk dari pemahan. Sedangkan pengertian dari pemahaman itu tersendiri ialah salah satu bentuk dari hasil belajar. Pemahaman juga bisa 
diartikan sebagai menguasai suatu hal dengan pikiran. Dengan pengertian pemahaman yang sudah dipaparkan bahwasannya belajar juga berarti harus paham secara mental. Pemahaman sangat penting bagi seorang mahasiswa alasannya karena dengan memahami pemahaman mahasiswa akan tau apa tujuan akhir dari setiap pembelajaran. Maka dari itu mahasiswa dituntut untuk meningkatkan pemahamannya agar saat proses belajar terasa menyenangkan dan ilmu yang di dapat lebih akurat.

2

Model pembelajaran problem based lerarning dan blended learning ini diharapkan bisa diaplikasikan dalam mata kuliah Algoritma pemprogaman untuk mengarahkan mahasiswa agar lebih aktif dan bekerja secara kelompok dari suatu masalah kemudian bisa diterapkan dalam bentuk kode program. Diharapkan juga dengan permasalahan yang ada bisa membuat suatu kode program yang akan menambah keterampilan mahasiswa dalam mata kuliah Algoritma Pemrograman.

\section{METODE}
A. Model Blended Learning

Desain eksperimen semu (quasi-experiment) dengan non equivalent control group design merupakan metode yang digunakan dari penelitian ini

1

Pada penelitian ini kelompok eksperimen memanfaatkan modelblended learning $\left(X_{1}\right)$ sedangkan kelompok kontrol menggunakan konvesional $\left(X_{2}\right)$.

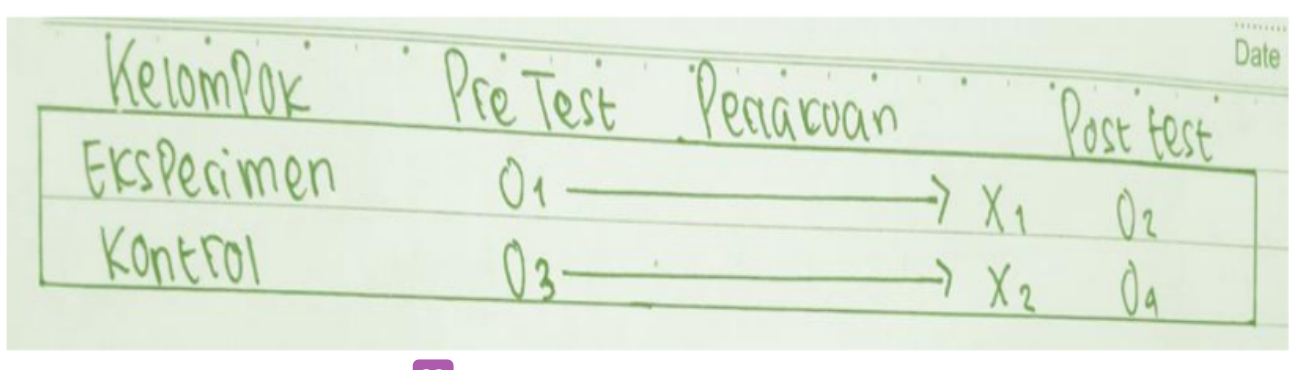

33

Gambar 1. Desain Penelitian 


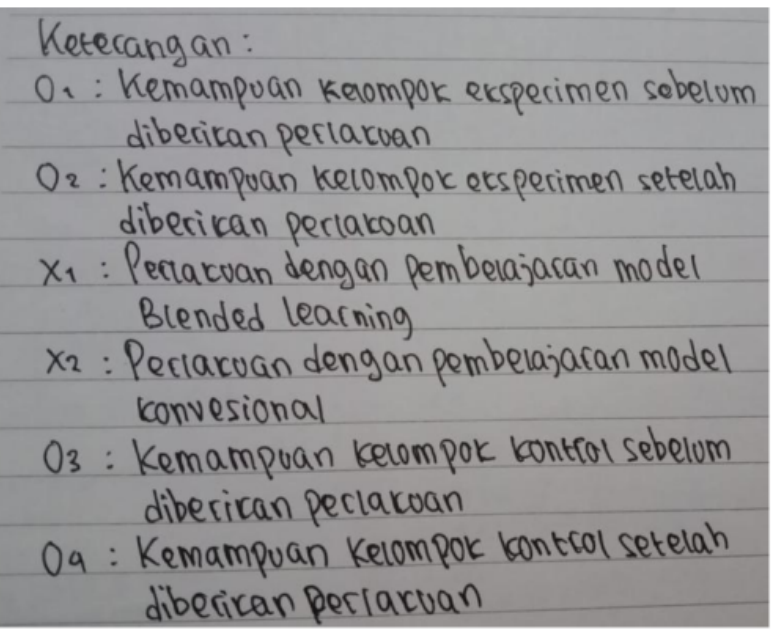

Pada kelompok eksperimen dan kelompok kontrol untuk mengukur efektivitas model blended learning maka dilaksanakannya pre test dan post tes. Cara melihat efektivitas dari model blended learning dengan cara melihat total pre test dan post pada kelompok kontrol dan kelompok eksperimen. Data dari penelitian ialah data skor dari motivasi dan tingkat pemahaman.

Dapat mengetahui motivasi dan tingkat pemahaman para mahasiswa dengan menggunakan model blended learning merupakan tujuan dari penelitian ini. Untuk dilakukannya pengujian efektivitas makan dilakukanlah percobaan yang disrumuskan dalam

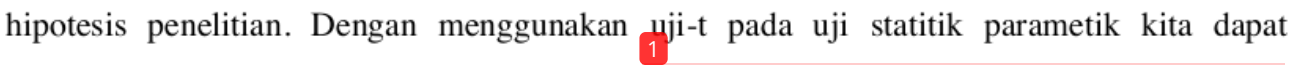
memeriksa signifikansi perbedaan mead pada lebih dari dua kelompok yang berlainan akibat dari beberapa perlakuan pengguna suatu variabel bebas. Sebelum melakukan pengujian, data yang diperoleh harus memiliki petisi dilakukannya dengan parametik tes diantaranya yaitu berdistribusi norma dan sama.

\section{B. Pengembanagan Modul}

Jenis observasi yang digunakan adalah Research and Development yang sering disebut sebagai penelitian pengembangan. Tahapan penelitian yang digunakan mengacu pada Thiagarajan (1974), yang dikenal dengan 4D yaitu define, design, develop, dan disseminate. Tetapsi, untuk tashap disseminate tidak dilakukan dalam penelitian ini dikarenakan dependensi waktu. 
HASIL

A. Model Blended Learning

$\underset{1}{1}$ Hasil analisis hipotesis 1 memanfaatkan data motivasi akhir kelas eksperimen dan kontrol. Untuk menguji hipotesis 1 maka digunakanlah uji t dengan taraf signifikan 0,05 .

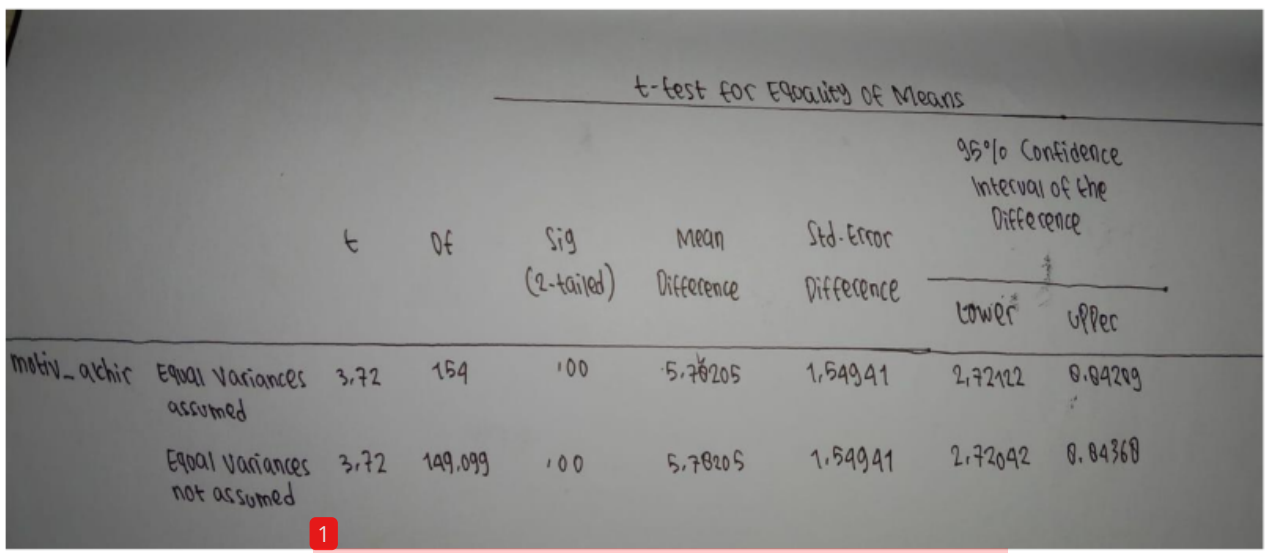

Output Independent Samples Test Motivasi Belajar

Kelas Eksperimen dan Kelas Kontrol

Hasil dari uji hipotesis diatas adalah motivasi akhir kelas eksperimen terhadap kelas kontrol memberikan nilai signifikansi $0,000<$ signifikansi 0,05 . maka rata-rata fari perbedaan motivasi antara kelas eksperimen dan kelas kontrol yaitu 5,782 . maka dapat di simpulkan yaitu bahwasannya terdapat perbedan motivasi belajar pada mahasiswasetelah mengikuti model pembelajaran blanded learning dengan mahasiswa yang mengikuti pembelajaran model konvesional.

Perbedaan dari rata-rata motivasi akhir bealajar mahasiswa antara kelas eksperimen dan kelas kontrol disajikan dapat dilihat di bawah ini. 


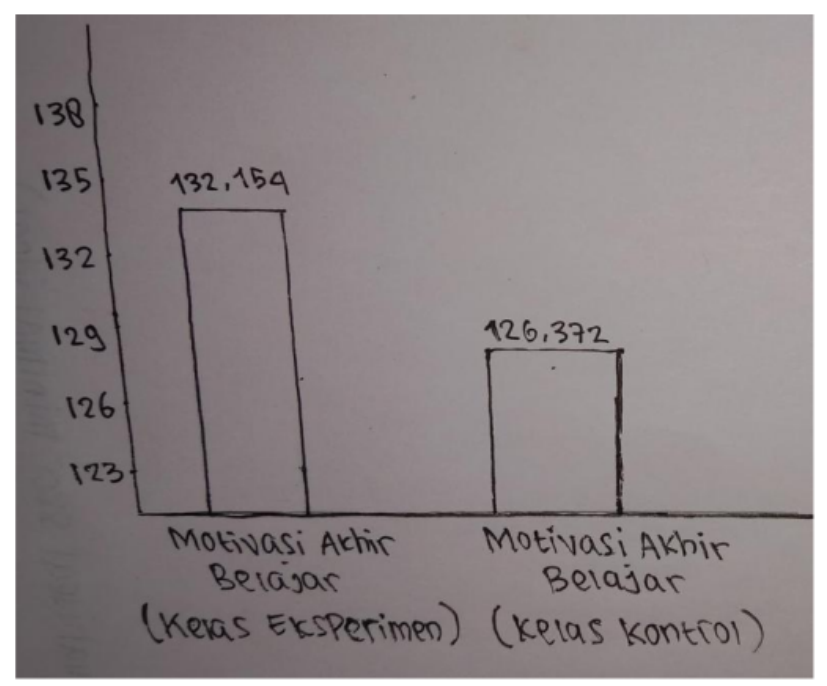

Gambar 2. Rata-Rata Motivasi Akhir Belajar dari Kelas Eksperimen dan Kontrol

Perhitungan yang menggunakan uji t pada hasil analisis hipotesis 2 pada tingkat pemahaman dari kelas eksperimen dan kelas kontrol menggunakan data pottest.

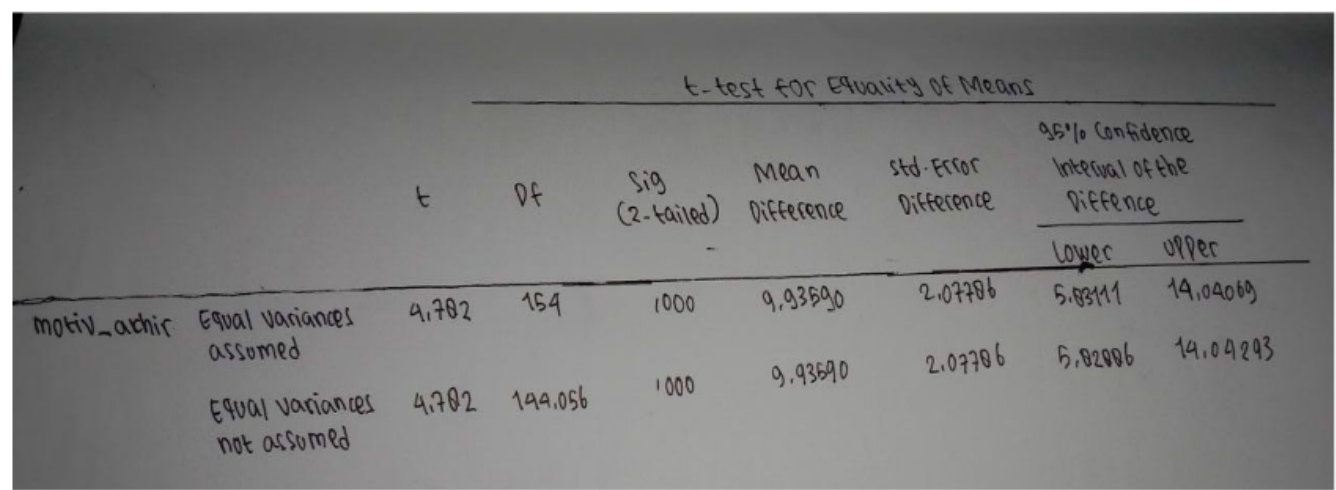

1

Output Independent Samples Test Tingkat Pemahaman

\section{Kelas Eksperimen dan Kelas Kontrol}

Hasil dari analisis diatas yaitu bahwa pottest kelas eksperimen terhadap kelas kontrol memberikan nilai signifikansi $0,000<$ signifikansi 0,05 . Maka dari itu terdapat sebesar 9,935 pada perbedaan rata-rata pottest dari kelas eksperimen $\underset{3}{d_{3}}$ kelas kontrol. Dan dapat disimpulkan bahwa perbedaan dari tingkat pemahaman mahasiswa setelah mengikuti pembelajaran model blended learning dengan mahasiswa yang mengikuti pembelajaran model konvesional. 
Perbedaan dari rata-rata pottest mahasiswa anatar kelas eksperimen dan kontrol disajikan pada gambar di bawah ini.

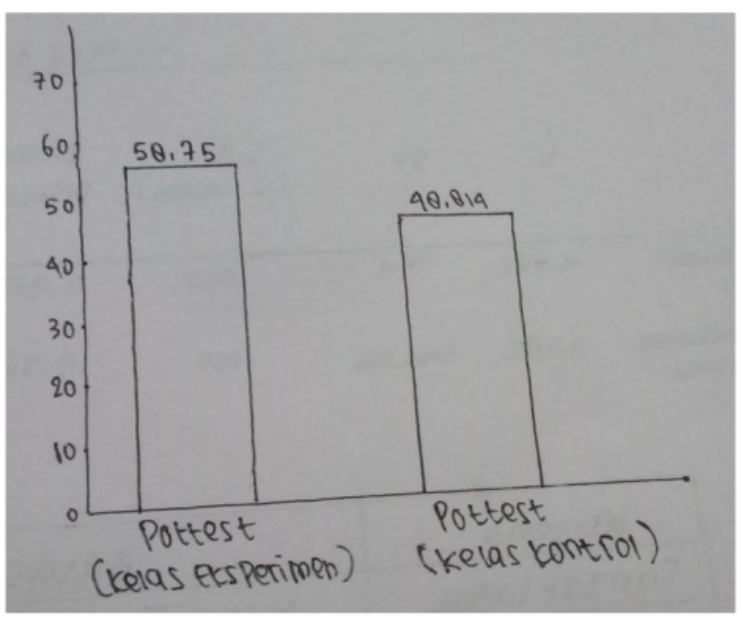

Gambar 3. Rata-Rata Posstest pada Kelas Eksperimen dan Kontrol

Hasil dari hipotesis 3 menggunakan data skor motivasi belajar sebelum dan sesudah pembelajaran blended learning. Pengujian menggunakan uji t paired samples test. Dengan menggunakan taraf siginifikasnsi 0,05 . Maka diperoleh bahwa terdapat peningkatan motivasi belajar mahasiwa akibat penerapan pembelajaran blended learning, dengan nilai signifikansi $0,000<$ nilai signifikansi 0,05 .

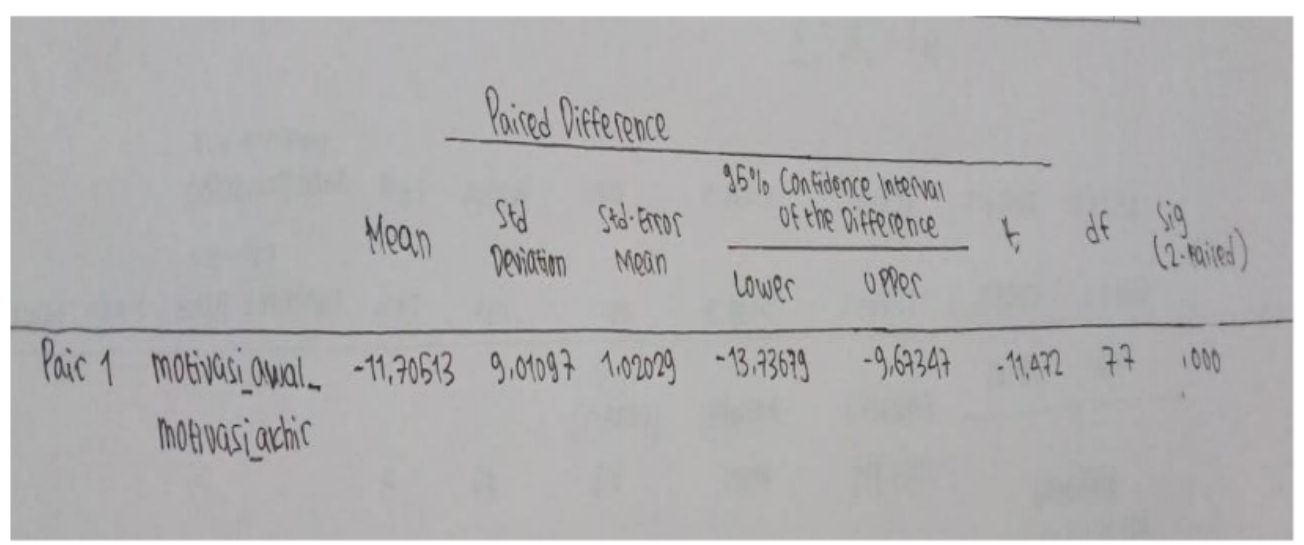

Output Paired Samples Test Untuk Hipotesis 3 


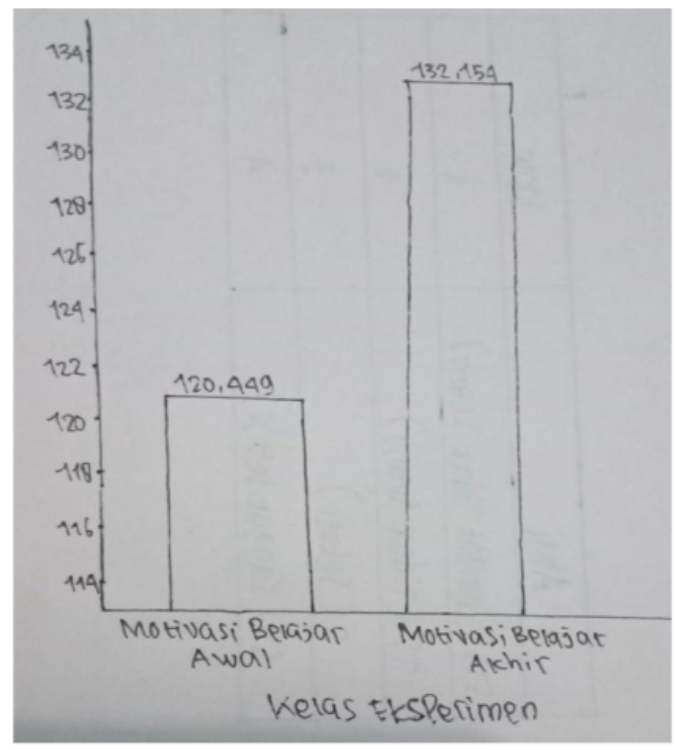

9

Gambar 4. Rata-Rata Motivasi Belajar Sebelum dan Sesudah Penerapan Blended Learning

Berdasarkan gambar diatas dapat dilihat rata-rata skor dari motivasi belajar yang belum diukur dengan menggunakan pembelajaran blended learning sebesar 120,449. Sedangkan rata-rata dari yang sudah diberikan pembelajaran dengan menggunakan blended learning adalah sebesar 11,705 point. Maka dari itu akibar dari penerapan juga dapat dilihat dari tabel beikut ini.

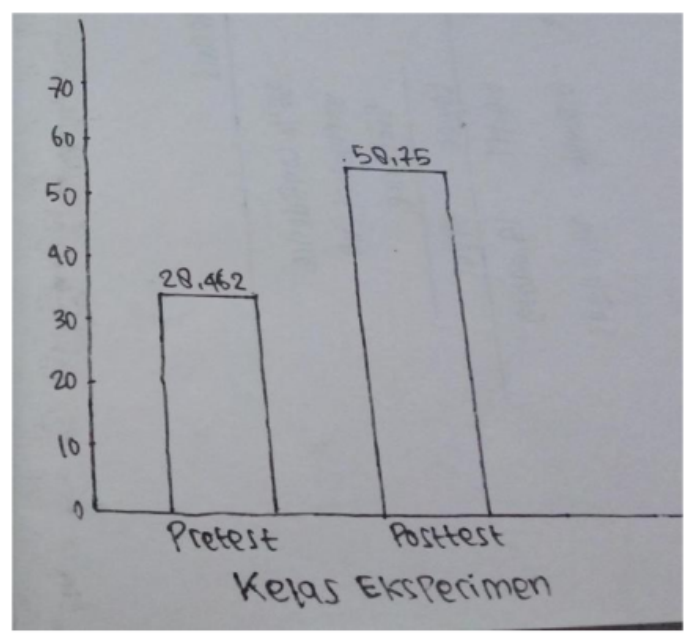

8

Gambar 5. Rata-Rata Tingkat Pemahaman Sebelum dan Sesudah Penerapan

Blended Learning 
Maka dapat disimpulkan bahwa rata-rata nilai pada tingkat pemahaman sebesar 28,462 merupakan skor yang didapat sebelum pembelajaran. Sedangkan nilai rata-rata sebesar 58,750 merupakan skor dari setelah diberikannya pembelajaran blended learning . Dari kedua angka tersebut dapat dilihat bahwa adanya peningkatan sebesar 30,288 point.

1

Berdasarkan hasil hipotesis satu terdapat perbedaan motivasi belajar mahasiswa. Nilai signifikansi sebesar 0,000 lebih kecil dari 0,05 merupakan nilai setelah mengikuti pembelajaran yang memakai pembelajaran model dean pembelajaran model konvesional. Sedangkan nilai sebesar 126, 371 adalah nilai mahasiswa kelas kontrol pada rata-rata skor motivasi belajar. Mahasiswa yang keaktifannya meningkat pada partisipasi dan perhatian pada saat proses pembelajaran adalah salah satu hal yang dapat dilihat adanya perbedaan dari peningkatan motivasi.

Berdasarkan hasil hipotesis dua terdapat perbedaan seperti dimana nilai signifikan yaitu sebesar 0,000 lebih kecil dari 0,5 yang terjadi pada mahasiswa setelah mengikuti pembelajaran model konvesional dengan pembelajaran model blended learning. Dengan adanya media online yang berbasis web sangat membantu para mahasiswa dalam meningkatkan kualitas belajara, karena web dapat menyediakan soal beserta lengkap dengan jawabannya. Maka dari itu mahasiswa dengan mudah apa yang menjadi kesulitan dalam mengetahui sebuah materi.

31

Berdasarkan hasil hipotesis tiga akibat penerapan pembelajaran blended learning dimana kenaikan pada motivasi belajar mahasiswa yaitu nilai signifikansi sebesar blended learning $0,000<0,05$. Pada pembelajaran dapat memadukan antara tatap muka dengan online. Hal ini dapat memunculkannya interaksi tidak hanya mahasiswa dengan dosen tetapi melainkan juga interaksi antar saling mahasiswa.

Berdasarkan hasil hipotesis empat akibat dari penerapan pembelajaran model blended learning ialah sebesar 28,462. Banyaknya sumber belajar yang bisa di akses tanpa adanya sumber batasan merupakan contoh dari kelebihan pembelajaran blended learning. Tidak hanya itu, pelaksanaan pembelajaran juga sangat efesien karena pemberian materi yang mandiri dan memerlukan penjelasan khusus.

B. Pengetahuan Modul 
Sesuai dengan penelitian pengembangan, maka hasil terfokus pada hasil evaluasi atau masukan-masukan pada saat menyusun modul. Tujuan uji coba pada produk tahapan pengembangan adalah agar adanya variasi prototype dari modul yang telah dibuat sampai pada tahap design. Tingkatan ini terdiri dari validasi modul dan uji coba modul.

Validasi modul dilakukan oleh dua pakar materi dan dua pakar media. Hal yang dilakukan seperti memberikan sebuah angket, di dalam angket tersebut terdapat beberapa aspek tentang yang diujikan dari modul. Panduan memperbaikan rancangan modul yang telah dibuat merupakan atas pendapat dan saran yang telah diperoleh dari pakar.

Selanjutnya dilakukan revisi dari hasil penilaian dan masukan para pakar. Kemudian, dilakukan eveluasi melalui uji coba modul pada subjek yang sesungguhnya, uji coba pertama terbatas hanya pada 5 mahasiswa saja. Dilakukan revisi modul berdasarkan masukan dari hasil uji coba utama yang melibatkan 29 mahasiswa prodi Pendidikan Matematika.

Tabel 1. Aturan Penskoran Angket Validasi

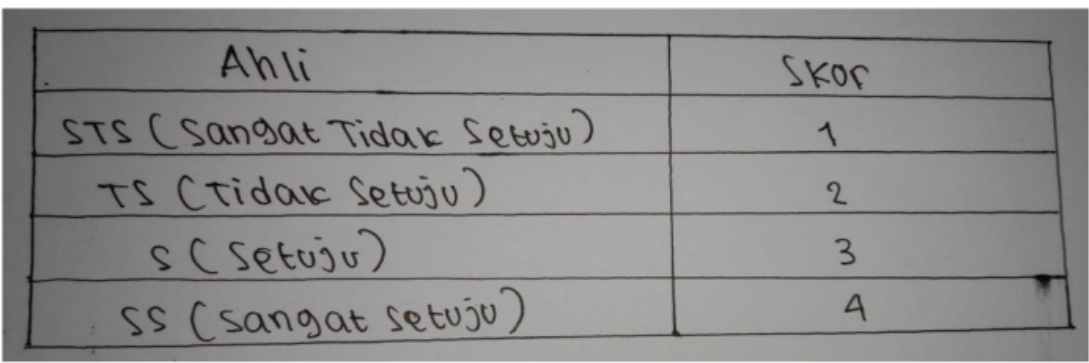

34

Rumus rata-rata yang digunakan adalah sebagai berikut
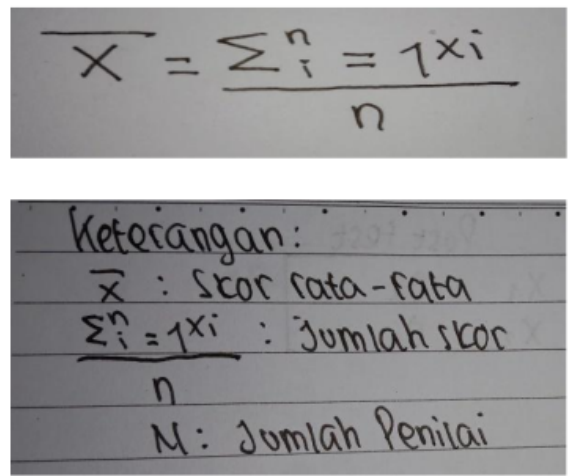
Data angket dirangkum dalam bentuk tabel.

Kriteria dan batas nilai serta perhitungan skor angket menurut Mardapi (2008) adalah sebagai berikut.

Tabel 2. Kriteria dan Batas Nilai
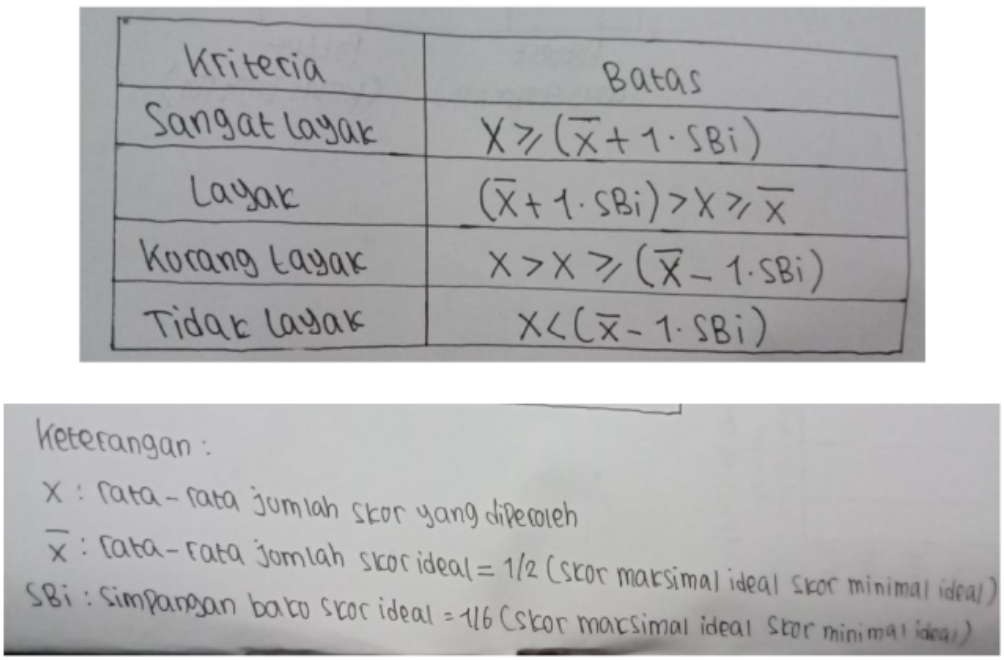

11

Adapun hasil validasi ahli materi disajikan dalam Tabel 3 berikut.

Tabel 3. Hasil Perhitungan

Nilai Rerata Ahli Materi

\begin{tabular}{|c|c|c|c|}
\hline No & Aspek Penilaian & Rerata Skor & Kategori \\
\hline $\mathbf{1}$ & Self Instruction & 61 & \\
\hline $\mathbf{2}$ & Self Contained & 4 & \\
\hline $\mathbf{3}$ & Stand Alone & 3 & \\
\hline $\mathbf{4}$ & Adaptive & 3.5 & \\
\hline $\mathbf{5}$ & User Friendly & 9.5 & \\
\hline $\mathbf{6}$ & Kemutakhiran Isi & 19 & \\
\hline $\mathbf{7}$ & Manfaat & 24 & Layak \\
\hline \multicolumn{2}{|c|}{ Total keseluruhan Rerata Skor penilaian } & $\mathbf{7 5}$ & \\
\hline
\end{tabular}


Skor dari rata-rata tersebut dikatakan sangat layak. Karena nilai berada pada $X \geq 105$. Dari total keseluruhan materi sebesar 124. Jika diubah ke bentuk persentase maka hasilnya adalah $88,57 \%$, nilai tersebut didapat dari rata-rata angket makar materi.

Pada penilaian ahli media aspek penilain pada grafika rata-rata skornya yaitu 106,5 dan aspek penilaian pada penyajian rata-rata skornya yaitu 40. Dan total dari keseluruhan rata0rata skor penilaian adalah 146,5 (termasuk ke dalam kategori layak).

Begitu juga skor rata-rata pada penilaian pakar media dikatakan sangat layak karena berada pada rentang skor $X \geq 138$ dari tital keseluruhan 146,5. Nilai 79,61\% merupakan nilai rata-rata yang didapat dari angket pkar media jika telah diubah ke dalam bentuk persen.

Kemudian dilakukan uji coba produk pada mahasiswa prodi pendidikan matetmatika yang mengambil mata kuliah Algoritma dan Pemprogaman. Kegiatan pengujian dilakukan dengan mahasiswa menggunakan modul dalam proses pembelajaran di kelas kemudian mengisi angket evaluasi. Mhasiswa yang terlibat dalam pengisian angket berjumlah 5 orang pada uji coba terbatas dan 29 mahasiswa pada uji coba utama. Setelah uji coba terbatas, modul direvisi kemudian dilakukan uji coba utama.

Pada hasil perhitungan nilai pengguna pada uji coba terbatas aspek penilain pada tampilan rata-rata skornya yaitu 19 , sedangkan pada penyajian materi rata-rata skornya yaitu 39 dan aspek penilaian dari manfaat rata-rata skornya adalah 17. Dan total pada keseluruhan rata-rata skor adalah 75 (termasuk ke dalam kategori layak).

Pada hasil perhitungan nilai pengguna uii coba utama aspek penilaian pada tampilan rata-rata skornya adalah 20, pada penyajian rata-rata skornya adalah 42 dan pada aspek penilaian manfaat rata-rata skornya adalah 19. Dan total dari keseluruhan rata-rata skor penilaian adalah 81 (termasuk kedalam kategori yang sangat layak).

Total keseluruhan rata-rata skor penilaian pengguna pada uji coba terbatas sebesar 75 yang berada pada rentang skor $76>X \geq 63$ berdasar tabel kriteria dan batas nilai. Skor tersebut termasuk kategori layak ${ }_{2}$ sedangkan jumlah semua rata-rata skor penilaian pengguna pada uji coba utama sebesar 81 yang berada pada rentang skor $X \geq 76$, yang termasuk dalam kategori sangat layak. Nilai $75 \%$ dan $81 \%$ merupakah hasil dari nilai uji coba terbatas dan nilai uji coba utama jika di ubah ke dalam bentuk persen.

Hasil validasi kelayakan dari ahli materi, ahli media, dan uji coba pada pengguna mahasiswa dapat disajikan dalam grafik berikut ini. 


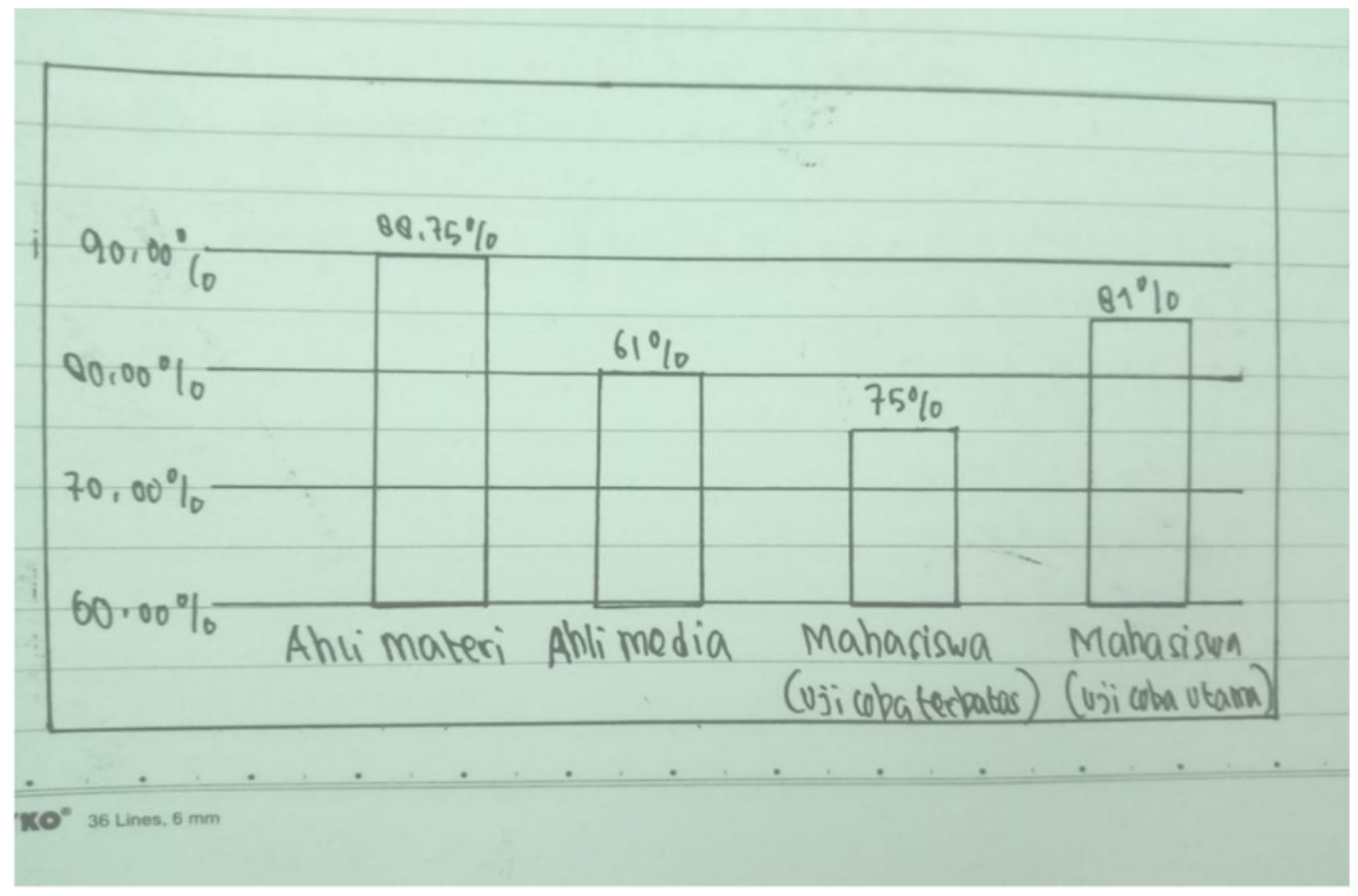

Gambar 6. Grafik Persentase Kelayakan Modul Algoritma dan Pemprogaman

Berdasarkan pembahasan yang dipaparkan diatas, bahwasannya menujukkan modul sangat layak pada pengujian ahli materi, ahli media, dan mahasiswa. Hal lain yang juga dapat disimpulkan adalah dengan adanya modul algoritma dan pemrograman dapat membantu baik pada dosen maupun pada mahasiswa pada saat kegiatan pembelajaran prodi pendidikan matematika. 


\section{KESIMPULAN}

21

Berdasarkan penjelasan dan data di atas maka dapat disimpulkan bahwa terdapat perbedaan yang signifikan terhadap motivasi belajar dan tingkat pemahaman mahasiswa yang telah menggunakan model blended learning dengan kelas yang menggunakan model konvesional pada mata kuliah algoritma dan pemrograman. Tingkat pemahaman mahasiswa memiliki perbedaan yang signifikan antara kelas yang menggunakan model blended learning dengan kelas yang menggunakan model konvesional. Motivasi belajar mahasiswa mengalami kenaikan secara signifikan dikarenakan penerapan model blended learning dan juga tingkat pemahaman mahasiswa mengalami kenaikan karena penerapan model blended learning dan berdasarkan uraian dan data di atas, maka disimpulkan bahwa yaitu hasil akhir produk yang dikembangkan berupa modul mata ilmu pemrograman yang sesuai dengan karakteristik mahasiswa prodi pendidikan matematika serta modyl yang dihasilkan memiliki kriteria sangat layak yang berdasarkan pada hasil validasi ahli materi, ahli media, dan uji coba mahasiswa. Hasil validasi modul oleh ahli media yaitu $79.61 \%$, dan uji coba utama pada mahasiswa memperoleh nilai $81 \%$.

\section{DAFTAR PUSTAKA}

Abdul, K. (2012). Algoritma dan Pemprograman menggunakan java. Yogyakarta : Andi offset

A.G. (2016). Learning Sebagai Peran Teknologi Informasi Dalam Modernisasi Pendidikan. Jurnal Sist Inf Univ Suryadarma

Dharmawati, W., \& Oktarika, D. (2019) Pengembanagan Media Pembelajaran Berbasis Multimedia Interaktif untuk Guru Ipa Di Sekolah. Jurnal Pendidikan Informatika dan Sains

Hamadin, dkk. (2015). Pengembanagan Media Pembelajaran Interaktif Berbasis Tik Dengan Pendekatan Saintifik. Jurnal fkip Unila

10 Laili, I. (2019). Efektivitas Pengembangan E-Modul Project Based Learning Pada Mata Pelajaran Instlasi. Jurnal Ilmiah Pendidikan dan Pembelajaran

Pribadi, A. B. (2009). Model Desain Sistem Pembelajaran. Jakarta : Dian Rakyat 
Sanjaya, W. (2009). Strategi Pembelajaran Bereorentasi Standar Proses Pendidikan. Jakarta :

Penada Media Grup

Sudarman. (2016). Problem Based Learning : Suatu Model Pembelajaran untuk Mengembangkan dan Meningkatkan Pemecahan Masalah. Jurnal Pendidikan Inovatif

Suparman . (2015). Peningkatan Kemandirian Belajar dan Minat Belajar Mahasiswa Mata

Kuliah Elektronika Analog dengan Pembelajaran PBL. Jurnal Pendidikan Teknologi dan Kejuruan

Sulistyyohati, A. (2020). Pengukuran Learning Pada Mhasiswa Sebagai Upaya Penerapan

Pembelajaran Jarak Jauh. Jurnal Pendidikan Informatika

Syaharuddin, S., \& Mandailina, V. (2017) Pengembangan Modul Pemprograman Komputer

Berbasis Matlab. Jurnal Teori dan Aplikasi Matematika.

Zaenal, Abidin, Motivasi dalam strategi pembelajaran dengan pendekatan ARCS. Jurnal

Fakultas Agama Islam Universitas Muhammadiyah Surakarta. 
Artikel revisi sai

ORIGINALITY REPORT

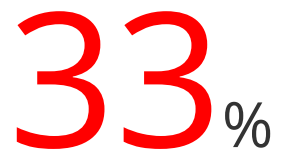

SIMILARITY INDEX
$32 \%$

INTERNET SOURCES

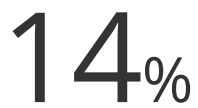

PUBLICATIONS
$20 \%$

STUDENT PAPERS

PRIMARY SOURCES

1 journal.uny.ac.id

Internet Source

2 eprints.uny.ac.id Internet Source

3 Submitted to Program Pascasarjana Universitas Negeri Yogyakarta Student Paper

4 ejournal.ihdn.ac.id Internet Source

5 publikasi.fkip-unsam.org Internet Source

6 Submitted to Universitas Negeri Jakarta Student Paper

7 manajemen.fe.um.ac.id Internet Source

8 id.scribd.com 
10 jptk.ppj.unp.ac.id

11 jurnal.unimed.ac.id

15 zombiedoc.com

Internet Source

16 Submitted to Universitas Islam Negeri

Sumatera Utara

Student Paper

17 Yunis Sulistyorini, Dian Fitri Argarini.

"Pengembangan Modul Analisis Vektor

Terintegrasi Media Pembelajaran Prezi",

Laplace : Jurnal Pendidikan Matematika, 2019

Publication

journal.universitassuryadarma.ac.id 
22 jurnalmahasiswa.stiesia.ac.id

Fifit Firmadani, Mashud Syahroni.

"PENGEMBANGAN MODUL MATA KULIAH

MANAJEMEN PENDIDIKAN BERBASIS HOTS",

Jurnal Review Pendidikan dan Pengajaran,

2020

Publication

24

Submitted to Universitas Pendidikan Indonesia

Student Paper

25 ejournal.ikado.ac.id

Internet Source

26 jayhomalindo.blogspot.com

27 journal.uinjkt.ac.id 
Billy Hendrik, Mardhiah Masril, Firdaus

Firdaus. "Meningkatkan Kemandirian Belajar

Mahasiswa Melalui Penerapan Blended

Learning pada Mata Kuliah Algoritma dan

Pemrograman I", EDUKATIF : JURNAL ILMU

PENDIDIKAN, 2021

Publication

31

Tiara Nurhayati, Mohamad Agung

Rokhimawan, Ragil Dian Purnama Putri.

"Pembelajaran Model Blended Learning pada

Mata Kuliah Sains Lanjut dengan

Menggunakan Kurikulum KKNI", Jurnal

Basicedu, 2021

Publication

32

ejournal3.undip.ac.id

Internet Source

33 media.neliti.com

Internet Source

34 repositori.uin-alauddin.ac.id

Internet Source

35 spiritsumbar.com

Internet Source 
Exclude bibliography On 